\author{
Doc. dr. sc. Mijo Galiot, \\ sudac Općinskog suda u Splitu \\ Silvio Čović, \\ predsjednik Upravnog suda u Splitu
}

\title{
ODGOVORNOST ZA NAMJEŠTANJE REZULTATA SPORTSKIH NATJECANJA S ASPEKTA PODMIĆIVANJA
}

\author{
UDK: $343.352: 796 / 799$ \\ DOI: $10.31141 /$ zrpfs.2021.58.139.315 \\ Pregledni rad \\ Primljeno: 1. studenog 2020.
}

Procesi modernizacije, globalizacije i konzumerizma bitno su promijenili odnos ljudi prema sportu i sportskim natjecanjima u suvremenom društvu. Sportska natjecanja postaju dramatičan izraz realnih kapitalističkih zbivanja i odnosa u kojima je, osim postizanja sportskih rezultata, glavni cilj maksimiziranje profita. Da bi se on ostvario, osobe u sustavu sporta, ali i subjekti povezani s klađenjem, nerijetko poduzimaju radnje s ciljem namještanja rezultata sportskih natjecanja. Riječ je ponajprije o koruptivnoj pojavi koja podliježe sankcioniranju i prema normama kaznenog prava. U ovom radu analizirat će se pozitivno pravno uređenje kaznene odgovornosti za podmićivanje zbog namještanja rezultata sportskih natjecanja. Razmotrit će se i pojavni oblici navedenih radnji te kritički preispitati mogućnost kažnjavanja sudionika tih protupravnih radnji samo s aspekta kaznene odgovornosti za počinjenje djela davanja mita i primanja mita. U kaznenoj praksi pokazalo se spornim podvođenje sudionika sportskih natjecanja pod pojam odgovorne osobe kako je on definiran u Kaznenom zakonu, te je li se koruptivne radnje poduzete s ciljem manipulacije rezultatima sportskih natjecanja mogu podvesti pod službenu radnju u kontekstu odgovornosti za počinjenje tzv. klasičnih oblika aktivnog i pasivnog podmićivanja. Polazeći od pozitivnopravnog uređenja u hrvatskom zakonodavstvu i pravnih shvaćanja tzv. uskočke prakse, pokušalo se istražiti u kojo j je mjeri moguć kazneni progon i kažnjavanje sudionika sportskih natjecanja za podmićivanje zbog namještanja rezultata. Zaključuje se o potrebi „de lege ferenda“ izmjene zakonskog uređenja i kritičkog preispitivanja pravnih stajališta koja su zauzeta u kaznenoj praksi.

Ključne riječi: sport, sportsko natjecanje, namještanje rezultata, kaznena odgovornost, podmićivanje, davanje mita, primanje mita 


\section{UVOD}

Tema sporta ${ }^{1}$ kao života, strasti, ali i biznisa, a zapravo naporna potraga za onom oštrom linijom koja dijeli sport na dio koji je krucijalni kulturni element svakoga društva te na dio koji predstavlja itekako značajnu ekonomsku aktivnost, sve je privlačnija tema multidisciplinarnoga znanstvenog interesa. ${ }^{2}$

Kad u prvim desetljećima 20. stoljeća sport postaje objektom masovne potrošnje kao dio konzumerizma bez presedana, a novi stadioni izgrađeni u pretencioznom imperijalnom stilu postaju pozornicama nesmiljene profesionalizacije i etike zabave (entertainment ethic), nestaje granica između ritualnog svijeta igre i natjecateljske stvarnosti kapitalizma. ${ }^{3}$ Sport je danas organizirani globalni fenomen koji kombinira fizičko natjecanje s profesionalnim vodstvom, trgovinom i investicijskim odnosima koji prelaze nacionalne granice. ${ }^{4}$ Svi veliki sportski događaji s međunarodnom dimenzijom, još jednom su pokazali da je sport odavno postao predmet političkog interesa najvišeg reda. ${ }^{5}$ Klasičnu i originalnu koncepciju sporta, koja je u njemu isključivo gledala način promocije pojedinaca, fizičkih i moralnih vrednota istaknute osobe, u suvremenom sportu je zamijenila krajnje suprotna koncepcija trijumfirajućeg nacionalizma kojoj danas svjedoče svi: publika, mediji, države. ${ }^{6}$ Stoga je sport najjeftinije, najpristupačnije i najčišće oružje u državnim konfliktima. ${ }^{7}$ Sport je i refleksija i odraz stanja unutar svakog pojedinog društva, a pogotovo hrvatskog, s obzirom na njegovu tradiciju. ${ }^{8}$

Procesi modernizacije, globalizacije i konzumerizma bitno su promijenili odnos ljudi prema sportu i sportskim natjecanjima u suvremenom vremenu. Sportska natjecanja postaju dramatičan izraz realnih kapitalističkih zbivanja i odnosa u kojima je, osim postizanja sportskih rezultata, glavni cilj maksimiziranje profita. Da bi se on ostvario, osobe u sustavu sporta, ali i subjekti povezani s klađenjem, nerijetko poduzimaju radnje s ciljem namještanja rezultata sportskih natjecanja. Ta se pojava, isprepletena s organiziranim kriminalnim mrežama, aktivnim na globalnoj

1 Prema definiciji Vijeća Europe, sport predstavlja svaki oblik fizičke aktivnosti koji, kroz povremeno ili organizirano sudjelovanje, stremi izražavanju ili poboljšavanju fizičke spremnosti i mentalnog zdravlja, formiranju društvenih odnosa ili postizanju rezultata u natjecanju na svim razinama - tako Bačić, A., Bačić P., „Lisabonski ugovor i novi start europskog sportskog prava“, Zbornik radova Pravnog fakulteta u Splitu, Split, 4/2011, str. 681.

2 Bačić, Bačić (2011.), op. cit. (bilj. 1.), str. 682.

3 Bačić, A., Bačić P., „Stadion i ustavno pravo: treba li sport i sportska prava shvaćati ozbiljno?“, Zbornik radova Pravnog fakulteta u Splitu, Split, 2/2010, str. 241.

4 Ibidem, str. 251.

5 Ibidem, str. 253.

6 Ibidem.

7 Ibidem.

8 Usp. Temeljna načela i smjernice razvoja športa u Republici Hrvatskoj od 15. veljače 2011. (str. 11.), koje je usvojilo Nacionalno vijeće za šport (dostupno na: www.sdus.gov.hr, 15. V. 2020.). 
razini, općenito se smatra jednom od najvećih prijetnji za sport danas. ${ }^{9}$ Tako se potkopavaju temeljne vrijednosti sporta, integritet, fair-play i poštovanje prema drugima. ${ }^{10}$ Sportski djelatnici su svojim ponašanjem $u$ obvezi osigurati uvažavanje sportskog protivnika, gledatelja i sportskih organizacija, zalagati se za punu regularnost sportskih natjecanja, suzdržavati se od nedopuštenih radnji, te stremiti afirmaciji i popularizaciji sporta, poštenju i časti i ostalim ponašanjima kojima se on promiče. U suprotnom postoji opasnost da zbog toga navijači i ljubitelji sporta izgube interes za organizirani sport. ${ }^{11}$ Riječ je o problemu koji je za sada prioritet za tijela javne vlasti, sportski pokret i tijela za provedbu zakona u cijelom svijetu. ${ }^{12}$

\subsection{Općenito o kaznenoj odgovornosti fizičkih osoba u sustavu sporta u kontekstu podmićivanja}

Kažnjavanje nesportskog ponašanja donošenjem i primjenom strogih disciplinskih pravila štite se sportski ideali i načelo poštene igre. ${ }^{13}$ No, zbog limitiranoga učinka stegovnih kazni, i šire pojavnosti protupravnoga koruptivnog ponašanja u vidu podmićivanja, u kontekstu odvijanja sportskih natjecanja, pokazalo se nužnim za intervenciju, osim sportskog, ${ }^{14}$ štoviše i kaznenog prava. ${ }^{15}$ Naime, riječ je ponajprije o koruptivnoj pojavi koja, iako je prisutna u sportu, ${ }^{16}$ prema istraženoj praksi kaznenih sudova, podliježe sankcioniranju prema normama kaznenog prava, kojima su uređeni tzv. klasični oblici aktivnog i pasivnog podmićivanja u javnom sektoru. ${ }^{17}$

9 Iz obrazloženja Prijedloga Odluke Vijeća Europe o potpisivanju, u ime Europske unije, Konvencije Vijeća Europe o manipulaciji sportskim natjecanjima s obzirom na pitanja koja nisu povezana $\mathrm{s}$ materijalnim kaznenim pravom i pravosudnom suradnjom u kaznenim stvarima, str. 1. (dostupno na: https://eur-lex.europa.html?uri=cellar, 15. V. 2020.).

10 Ibidem.

11 Ibidem.

12 Ibidem.

13 Pajčić, M., Sokanović, L., „Manipulacija rezultatima sportskih natjecanja - Kaznenopravna odgovornost za kazneno djelo prijevare“, Zbornik radova Pravnog fakulteta u Splitu, Split, 4/2011, str. 858 .

14 Kačer, H., Kačer B., Čizmić, J., „Citius-Altius-Fortius (Više, brže, jače)“, u Kačer, H. (ur.), Sportsko pravo (udžbenik), Pravni fakultet Sveučilišta u Splitu, Split, 2018., str. 15.

15 Usp. ibidem.

16 Sport bi trebalo definirati kao fizičku djelatnost kojom se ljudi bave, kako radi zdravlja, tako $i$ radi natjecanja i/ili rekreacije - tako Kačer, Kačer, Čizmić (2018.), op. cit. (bilj. 14), str. 17. Isti autori su, pri definiranju toga pojma, istaknuli: Prava je šteta što pojam sporta nema svoju zakonsku definiciju, nego je treba neizravno izvoditi, što nikako nije jednako, barem ne prema kriteriju pravne sigurnosti i vladavine prava koji su temelji svake, baš svake pravne države. Kačer, Kačer, Čizmić (2018.), op. cit. (bilj. 14), str. 15.

17 O odnosu sportskog prava prema drugim granama prava v. Kačer, Kačer, Čizmić (2018.), op. cit. (bilj. 14), str. 17 i 18. 
Doc. dr. sc. Mijo Galiot i Silvio Čović, dipl. iur.: Odgovornost za namještanje rezultata sportskih natjecanja... Zbornik radova Pravnog fakulteta u Splitu, god. 58, 1/2021, str. 315-348

Ako je riječ o kaznenoj odgovornosti ${ }^{18}$ fizičkih osoba u djelatnosti sporta, bitno je utvrditi u kojim situacijama protiv tih osoba može doći do kaznenog progona. ${ }^{19}$ Istraživanje tih situacija ograničit će se samo na kaznenu odgovornost za počinjenje djela primanja mita i davanja mita. Pritom, valja uzeti u obzir da su, iako je riječ uglavnom o koruptivnim deliktima susretanja (tzv. zrcalnim djelima), njihova posebna obilježja različita s obzirom na krug potencijalnih (su)počinitelja i sudionika u koruptivnoj razmjeni.

Kazneno djelo davanja mita, u pravilu, može počiniti svatko. Kao počinitelji ili supočinitelji kaznenih djela aktivnog podmićivanja mogu se pojaviti različiti subjekti za razliku od primanja mita koje spada u kategoriju delicta propria. ${ }^{20}$ Stoga ona spadaju u kategoriju delicta communia. To znači i da se, kao potencijalni počinitelji tih kaznenih djela, mogu pojaviti i službena ili odgovorna osoba, ali to u praksi ne mora tako biti, a najčešće i nije. Naime, praksa je pokazala da se službene ili odgovorne osobe, u pravilu, nalaze na strani suprotnoj činiteljima aktivnog podmićivanja. To je i razumljivo, budući da su radnje aktivnog podmićivanja uvijek usmjerene na službene ili odgovorne osobe ili zastupnike, ako je riječ o djelu podmićivanja zastupnika. ${ }^{21}$ Svojstvo počinitelja kao službene ili odgovorne osobe nije konstitutivno obilježje bića kaznenih djela aktivnog podmićivanja, ali jest kaznenih djela pasivnog podmićivanja. ${ }^{22}$ No, neke od inkriminacija aktivnog podmićivanja, posebno ona iz skupine protiv službene dužnosti, ${ }^{23}$ mogu se počiniti samo ako su radnje podmićivanja obavljene u odnosu na službenu ili odgovornu osobu. $^{24}$

18 Kaznena djela jesu djela ljudske radnje kojima se povređuju ili ugrožavaju temeljne individualne i društvene vrijednosti zajamčene Ustavom i međunarodnim pravom, koje su zakonom ili međunarodnim pravom predviđene kao kaznena djela, a ostvarena su na protupravan i skrivljeni način - tako Kurtović, A., Krstulović Dragičević A., Kazneno pravo (Temeljni pojmovi i instituti), Udžbenici Sveučilišta u Splitu, Split, 2014., str. 4.

19 Usp. Primorac, D., „Šport i protupravna ponašanja“, u Kačer, H. (gl. ur.), (Uvod u) Sportsko pravo, Inženjerski biro, Zagreb, 2009., str. 340.

20 Valja razlikovati dvije kategorije delicta propria: a) prava delicta propria - kod kojih je svojstvo službene osobe njihovo konstitutivno obilježje i b) neprava delicta propria - kod kojih svojstvo službene osobe nije konstitutivno, ali ima kvalifikatorno obilježje.

21 V. čl. 339. KZ-a.

22 Tako je Ustavni sud u odlukama broj U-III-602/2014, U-III-1091/2014 i U-III-681/2014 od 5. srpnja 2016. (dostupne na: www.usud.hr) istaknuo da kazneno djelo protiv službene dužnosti - primanje mita iz čl. 347. KZ/97-a pripada skupini tzv. delicta propria, to jest posebnih kaznenih djela koja mogu počiniti samo osobe s određenim svojstvom. Naime, svojstvo počinitelja kao ,službene ili odgovorne osobe“ konstitutivno je obilježje bića kaznenog djela primanja mita. Kao i svako drugo obilježje, i svojstvo počinitelja sud mora nedvojbeno utvrditi na temelju provedenog dokaznog postupka. O tomu da je ta okolnost utvrđena sudovi se moraju očitovati u obrazloženju presude. Ako se ta pravno relevantna činjenica u postupku ne utvrdi, a s obzirom na to da se ista ne predmnijeva, tada nisu ostvarena sva obilježja kaznenog djela kao pretpostavka za utvrđivanje ostalih elemenata kaznenog djela, napose protupravnosti i krivnje.

23 Osim kaznenog djela davanja mita iz čl. 294. KZ-a u tu skupinu spada i kazneno djelo davanje mita za trgovanje utjecajem iz čl. 296. KZ-a.

24 Cijeli odjeljak čini navođenje dijela doktorske disertacije autora Galiot, M., Aktivno podmićivanje u hrvatskom kaznenom pravu i praksi, Zagreb, 2018., str. 183, 184 i 203 (disertacija predana neposredno od autora). 


\subsection{Zaštićeno pravno dobro kod djela davanja i primanja mita ${ }^{25}$}

Djela aktivnog i pasivnog podmićivanja u javnom sektoru zaštićuju interes i težnju cjelokupnog društva i svakog pojedinca za čistoćom, ispravnošću i zakonitošću u djelovanju državnih i drugih službi od javnog interesa, jer samo tako one ispunjavaju svoju društvenu funkciju, ali i interes svakog građana da te službe pravilno i zakonito funkcioniraju, a da se pritom ne dovodi u pitanje povjerenje javnosti u javni sektor. ${ }^{26}$ Dakle, objekt zaštite je zakonito i pravilno obavljanje službene dužnosti. Ili, jednostavnije izneseno, zaštićeno pravno dobro je službena dužnost. ${ }^{27}$

Inkriminacijom takvih ponašanja zakonodavac je KZ-om očito želio pravovremeno ukazati na protupravna ponašanja u službi, detektirati ih i suzbiti moguće zlouporabe javnih ovlasti od strane osoba zaposlenih u javnom sektoru. ${ }^{28}$ Krajnja je svrha bila zaštita društva i pojedinca od korumpiranosti državnog aparata i drugih javnih službi. ${ }^{29}$ Stoga se može reći da su zaštitni objekt te glavne i javne ovlasti - uži pojam od službene dužnosti.

Bačić i Pavlovic ${ }^{30}$ zaključili su da kaznena djela protiv službene dužnosti, iako se među njima uočavaju razlike s obzirom na opis radnje počinjenja, posljedica djela, motive počinjenja i ispunjenje objektivnih uvjeta njihova postojanja, povezuje njihovo zajedničko svojstvo i osnovno obilježje - povreda službene dužnosti. Oni smatraju da se pri određivanju inkriminacija pošlo od toga da se pojedincima koji rade u državnim tijelima povjeravaju posebne zadaće i ovlasti, koje u interesu dobrog stanja u zajednici - moraju uvijek uživati povjerenje javnosti da u obavljanju svojih dužnosti postupaju zakonito. ${ }^{31}$ Oni smatraju da je i kod ovih kaznenih djela težište na posebnoj biti njihova neprava, kao povredi zakonitog obavljanja službenih poslova, a ne na samom svojstvu službene osobe. ${ }^{32}$ Stoga zaključuju da iz navedenog proizlazi objekt kaznenopravne zaštite. ${ }^{33}$ Pritom razlikuju objekt kaznenopravne zaštite: a) u formalnom smislu i b) u materijalnom smislu. U formalnom smislu, objekt zaštite je zakonito obavljanje službenih, javnih i drugih ovlasti službene

25 Cijelo poglavlje 1.2. s neznatnim izmjenama čini navođenje dijela doktorske disertacije autora Galiot (2018.), op. cit. (bilj. 24), str. 175 i 176.

${ }_{26}$ Bačić, F., „Korupcija i antikorupcijsko kazneno pravo“, Hrvatski ljetopis za kazneno pravo $i$ praksu, 2000., str. 832.

27 Slično zaključio i Čejović: Krivična djela protiv službene dužnosti, na prvom mjestu, znače povredu službene dužnosti. To je dužnost posebne vrste koja proizlazi iz posebnog odnosa. Krivična djela protiv službene dužnosti predstavljaju povredu ove dužnosti $i$ uperena su protiv odgovarajućih službi $i$ njihovog pravilnog funkcioniranja - Čejović, B., Krivično pravo: Posebni deo, Naučna knjiga, Beograd, 1988., str. 362 .

${ }_{28}$ Tako Derenčinović, D., Cvitanović, L., Munivrana V., Turković, K., Posebni dio kaznenog prava, (ur.) Derenčinović, D., Pravni fakultet Sveučilišta u Zagrebu, Zagreb, 2013., str. 227.

29 Bačić, F., Pavlović, Š., Kazneno pravo - posebni dio, Informator, Zagreb, 2001., str. 488.

30 Bačić, F., Pavlović, Š., Komentar Kaznenog zakona, Organizator, Zagreb, 2004., Uvod (1. Legislativna kronologija), str 1155.

31 Ibidem.

32 Ibidem.

33 Ibid, str. 1156. 
i odgovorne osobe. U materijalnom smislu objekt zaštite je interes cjelokupnog društva i svakog pojedinca za čistoćom, ispravnošću i zakonitošću u djelovanju državnih i drugih službi od javnog interesa, jer samo tako one ispunjavaju svoju društvenu zadaću. ${ }^{34}$

\subsection{Postavljanje problema}

U sudskoj praksi, iako vrlo oskudnoj kada je riječ o kaznenoj odgovornosti osoba za počinjenje kaznenih djela davanja mita i primanja mita s ciljem namještanja rezultata sportskih natjecanja, pokazalo se spornim podvođenje sudionika tih natjecanja pod pojam odgovorne osobe, kako je on definiran u članku 87. stavku 6. Kaznenog zakona. ${ }^{35}$

Analizom sadržaja pravomoćnih odluka tzv. uskočkih sudova pokazalo se i dvojbenim je li se pojedine koruptivne radnje, poduzete s ciljem manipulacije rezultatima sportskih natjecanja, mogu podvesti pod službenu radnju u kontekstu odgovornosti za počinjenje tzv. klasičnih oblika aktivnog i pasivnog podmićivanja, te s obzirom na propisana konstitutivna obilježja tih kaznenih djela u tekstu (bićima) KZ-a.

34 Ibidem.

35 Kazneni zakon (NN, br. 125/11, 144/12, 56/15, 61/15, 101/17, 118/18 i 126/19, u daljnjem tekstu: $\mathrm{KZ})$. 
Doc. dr. sc. Mijo Galiot i Silvio Čović, dipl. iur.: Odgovornost za namještanje rezultata sportskih natjecanja... Zbornik radova Pravnog fakulteta u Splitu, god. 58, 1/2021, str. 315-348

Polazeći od analiziranoga zaštićenog pravnog dobra kod djela podmićivanja u javnom sektoru ${ }^{36}$ i distinkcije javnog ${ }^{37}$ od privatnog sektora, ${ }^{38}$ smatramo možda prijepornim primijeniti kazneno djelo primanja mita iz članka 293. KZ-a i davanja mita iz članka 294. KZ-a na pojedine sudionike sportskih natjecanja, pa čak i u situaciji kada bi ih se podvelo pod pojam odgovorne osobe. Drugačije izneseno, postavlja se pitanje je li se inkriminirane radnje pojedinih sudionika sportskih natjecanja u situacijama manipulacije rezultatima sportskih natjecanja mogu obuhvatiti kaznenim djelima davanja mita i primanja mita te, s tim u vezi, je li možda potrebno proširiti katalog kaznenih djela sadržan u KZ-u.

36 V. 1.2. Zaštićeno pravno dobro kod djela davanja mita i primanja mita.

37 Javni sektor sastoji se od: 1. opće države (središnje države te regionalnih i lokalnih državnih tijela), 2. nefinancijskih javnih poduzeća; 3. javnih financijskih institucija. Javnim nefinancijskim poduzećima smatraju se poduzeća u vlasništvu i/ili pod kontrolom države (javna poduzeća), a financijska poduzeća u vlasništvu ili pod kontrolom države (npr. središnja banka). Dakle, sektor opće države sastavni je dio javnog sektora. Državni sektor dio je javnog sektora, a obuhvaća sve državne jedinice čija je primarna uloga izvršavanje državnih funkcija (izvršne, zakonodavne i sudske). On obuhvaća sve nacionalne i subnacionalne državne jedinice, uključivši i izvanproračunske fondove, kao i neprofitne institucije koje pružaju netržišne usluge, a koje država financira i kontrolira. Prema terminologiji MMF-a kojom se definiraju pojmovi državnih financija (Government Finance Statistics Manual), državni se sektor naziva sektorom opće države. Stručni termin opća država u ovom će se pojmovniku upotrebljavati za označavanje pojma državnog sektora ili države. Pojam državni sektor ili država kolokvijalno se mnogo češće rabe za označavanje pojma koji se stručno naziva općom državom - izvor: www.ijf.hr>javnisektor>drzavni-sektor (19. V. 2020.). Javnoslužbenički odnos, prema određivanju pojma javne službe nužno je definirati, najjednostavnije, kao radni odnos između javnog službenika kao radnika te, u pravilu, države kao poslodavca. Unutar njega, sam radnopravni status javnih službenika možemo shvatiti kao ukupnost prava i dužnosti službenika utvrđenih propisom. Iz ove definicije proizlaze neke posebnosti tog radnopravnog odnosa u odnosu na tzv. „opće“ radne odnose koji su prisutni u privatnom sektoru. Prvo, vezano za subjekte, u javnoslužbeničkom odnosu poslodavac je, u pravilu, država. Drugo, javni službenici u obavljanju službe, u pravilu, nastupaju kao nositelji ovlasti državne vlasti, što nije karakteristično za privatni sektor. Treća bitna specifičnost javnoslužbeničkog odnosa ogleda se u tomu da poslodavac, država uređuje normativno službeničke odnose, a time i radni status javnog službenika. Dakle, država je i normotvorac i poslodavac. To ima za posljedicu da država, jedna od strana u službeničkom odnosu, može jednostrano promijeniti radnopravni status javnih službenika. To pravilo, međutim, nije prisutno u radnim odnosima unutar privatnog sektora. Četvrta specifičnost odnosi se na zasnivanje radnog odnosa, sastoji u tomu da javnoslužbenički odnos, u pravilu, ne nastaje sklapanjem ugovora o radu, već na temelju posebne odluke ili rješenja o prijmu u javnu službu ako je riječ o prijmu državnih službenika koji čine bitan dio javnog sektora. Ostale važne posebnosti javnoslužbeničkih odnosa, koje te odnose razlikuju od tzv. općih radnih odnosa u privatnom sektoru, odnose se na popunjavanje radnih mjesta, pravno uređenje plaća i drugih materijalnih prava, odgovornost službenika, prestanak radnog odnosa te zaštitu prava koja proizlaze iz njega - tako Galiot (2018.), op. cit. (bilj. 24), str. 16 i 17. Pod javnim sektorom neki autori podrazumijevaju sva javna i kvazijavna poduzeća u državnom ili većinskom državnom vlasništvu i opću državu koja obuhvaća sve izvršne, predstavničke i sudske jedinice čija je primarna uloga izvršavanje državnih funkcija te institucije koje provode javnu politiku i koje se financiraju fiskalnim i parafiskalnim nametima, tako Bejaković, P., Vukšić, G., Bratić, V., „Veličina javnog sektora u Republici Hrvatskoj“, Hrvatska i komparativna javna uprava, Zagreb, 2011, str. 101 i 102.

$38 \mathrm{U}$ nedostatku konkretnih definicija, smatramo da pod privatnim sektorom valja razumjeti područje slobodnog tržišnog djelovanja fizičkih osoba (obrtnika) i pravnih osoba koje su u privatnom vlasništvu ili u većinskom privatnom vlasništvu. Drugim riječima, privatni bi sektor simbolizirao poduzetništvo u Hrvatskoj i u tom slučaju pažnja je usmjerena samo na pravne osobe, odnosno na odgovorne osobe pravnih osoba - tako Galiot (2018.), op. cit. (bilj. 24), str. 15 i 16. Razlika između zaposlenih u javnom i privatnom sektoru ogleda se i u tomu što se rad zaposlenih u javnom sektoru plaća iz javnih sredstava i što je država zaposlenima u javnom sektoru istovremeno i poslodavac i zakonodavac. Država je ovdje poslodavac koji u svako doba može jednostrano promijeniti propise, time i odnose između sebe, kao poslodavca, i zaposlenih. Jovanović, Z., „Prava i dužnosti državnih službenika u Republici Srbiji“, Zbornik radova Pravnog fakulteta u Nišu, Niš, 2010., str. 227. 


\subsection{Cilj(evi) rada}

U ovom radu analizirat će se pozitivno pravno uređenje kaznene odgovornosti za podmićivanje zbog namještanja rezultata sportskih natjecanja samo s aspekta odgovornosti za počinjenje kaznenih djela davanja mita i primanja mita. Razmotrit će se i pojavni oblici navedenih protupravnih radnji. Polazeći od uvodnih analiza zaštićenog pravnog dobra kod djela aktivnog i pasivnog podmićivanja u javnom sektoru i temeljnih pravnih pojmova povezanih s odgovornošću za podmićivanje s ciljem manipulacije rezultatima sportskih natjecanja, ali i od pozitivnopravnog uređenja u hrvatskom zakonodavstvu i zauzetih pravnih shvaćanja, pokušalo se istražiti u kojoj je mjeri moguć kazneni progon i kažnjavanje sudionika sportskih natjecanja za kaznena djela primanja mita i davanja mita zbog namještanja rezultata tih natjecanja.

Zaključno će se kritički preispitati pravna stajališta, koja su zauzeta u sudskoj praksi te ćemo se očitovati o nužnosti izmjene pozitivnog zakonskoga uređenja u analiziranom dijelu.

Razlog odabira navedenoga predmeta istraživanja jest i posljedica toga da kaznenopravni fenomen (aktivnog i pasivnog) podmićivanja u sportu, mišljenja smo, nije dostatno istražen u doktrini. ${ }^{39}$

\section{KAZNENA ODGOVORNOST ZA PODMIĆIVANJE ZBOG NAMJEŠTANJA REZULTATA SPORTSKIH NATJECANJA}

U ovom dijelu rada ponajprije će se izložiti neki temeljni pojmovi koji su bitni za razmatranje kaznene odgovornosti za namještanje (manipulaciju) rezultata sportskih natjecanja. Potom će se obraditi pozitivno pravno uređenje kaznene odgovornosti za podmićivanje zbog namještanja rezultata sportskih natjecanja polazeći od europske pravne stečevine koja se bavi tom problematikom. Nakon toga izložit će se i analizirati recentna sudska praksa tzv. uskočkih sudova po konkretnoj tematici.

\subsection{Pravni pojmovi povezani s kaznenom odgovornošću za namještanje (manipulaciju) rezultata sportskih natjecanja}

U temeljne pojmove, koje smatramo bitnima za razmatranje kaznene odgovornosti za namještanje rezultata sportskih natjecanja, spadaju sljedeći pojmovi: a) sportsko natjecanje (i njegovi sudionici), b) namještanje (manipulacija) sportskih natjecanja, c) službena dužnost, d) odgovorna osoba i e) sportsko klađenje. Neki od tih pojmova definirani su međunarodnim pravom, neki kaznenim zakonodavstvom, neki normama primarno sportskog prava, a neki su definirani samo doktrinarno.

39 Usp. sa Sokanović, L., Šinković Z., Pajčić M., „Utaja poreza i drugih javnih davanja u sportu“, Zbornik radova Pravnog fakulteta u Splitu, Split, 4/2012, str. 804. 
Doc. dr. sc. Mijo Galiot i Silvio Čović, dipl. iur.: Odgovornost za namještanje rezultata sportskih natjecanja... Zbornik radova Pravnog fakulteta u Splitu, god. 58, 1/2021, str. 315-348

\subsubsection{Sportsko natjecanje i namještanje (manipulacija) sportskih natjecanja uz poseban osvrt na sudionike tih natjecanja}

Iako se u Zakonu o sportu, ${ }^{40}$ kao temeljnom izvoru sportskog prava, na više mjesta koristi kao postojeći pojam sportsko natjecanje s poznatim sadržajem, zakonodavac nije dao njegovu pobližu definiciju. ${ }^{41}$ Ako promatramo domaće zakonodavstvo, pojam športskog natjecanja definiran je Zakonom o sprečavanju nereda na športskim natjecanjima. ${ }^{42}$ Prema članku 3. toga zakona i u njegovom smislu športskim natjecanjem smatra se svako pojedino natjecanje u okviru sustava športskih natjecanja uspostavljenog na temelju Zakona o športu, u kome se natječu domaći i gostujući športski klub, međunarodno natjecanje organizirano na području Republike Hrvatske, natjecanje u sustavu europskih i svjetskih športskih organizacija, natjecanje za koje postoji procjena mogućnosti izbijanja nereda $i$ nasilja te natjecanje u inozemstvu u kojem sudjeluje reprezentacija ili športski klub iz Republike Hrvatske. Međutim, s aspekta postavljenoga cilja istraživanja, osobito je bitna definicija sportskog natjecanja, koja je sadržana u Konvenciji Vijeća Europe o manipulaciji športskim natjecanjima. ${ }^{43}$ Prema odredbi članka 3. stavku 1. Konvencije, športsko natjecanje znači svaki športski događaj organiziran u skladu s pravilima koje je odredila športska organizacija s popisa Odbora za praćenje Konvencije u skladu s člankom 31. stavkom 2. ${ }^{44} i$ koju je priznala međunarodna športska organizacija ili, prema potrebi, druge nadležne športske organizacije.

Povezano s definicijom pojma sportsko natjecanje, bitno je navesti i tko su osobe (ili subjekti) koje sudjeluju u sustavu sporta, pa i u sportskom natjecanju kao njegovom sastavnom dijelu. ZoS, u glavi IV. ${ }^{45}$ čini dvodiobu osoba u sustavu sporta. ${ }^{46}$ Tako je, člankom 5. stavkom 1., propisano da sustav sporta u Republici Hrvatskoj čine: a) fizičke osobe i b) pravne osobe uz školska sportska društva koja se osnivaju bez pravne osobnosti. Fizičke osobe u sustavu sporta su: a) sportaši, ${ }^{47}$

40 Zakon o sportu (NN, br. 71/06, 150/08, 124/10, 124/11, 86/12, 94/13, 85/15, 19/16, 98/19 i 47/20, u daljnjem tekstu: ZoS).

${ }_{41}$ Smatramo da je riječ o težem propustu normotvorca, koji se u tom dijelu nije vodio načelima pravne sigurnosti i vladavine prava, a koji su temelj svake uređene pravne države.

42 Zakon o sprečavanju nereda na športskim natjecanjima (NN, br. 117/03, 71/06, 43/09 i 34/11, u daljnjem tekstu: ZoSN).

43 Konvencija Vijeća Europe o manipulaciji športskim natjecanjima (The Convention on the Manipulation of Sports Competitions), u daljnjem tekstu: Konvencija (dostupno na: www.sdus.gov.hr i www.eur-lex.europa.eu., 16. V. 2020.). Konvencija je sklopljena u Magglingenu 18. rujna 2014., a nju je dosada potpisalo 37 država članica, među kojima i Republika Hrvatska 16. svibnja 2019.

44 Prema čl. 31. st. 2. Konvencije Odbor za praćenje Konvencije donosi i mijenja popis športskih organizacija iz članka 3. stavka 2. te osigurava objavu tog popisa na odgovarajući način.

45 Glava IV. Sustav sporta i sportske djelatnosti.

46 Kačer, H., Kačer B., „Osobe (ili subjekti) u sustavu sporta u hrvatskom pravu“, u Kačer, H. (ur.), Sportsko pravo (udžbenik), Pravni fakultet Sveučilišta u Splitu, Split, 2018., str. 39.

47 Sportaš u smislu ZoS-a jest osoba koja se priprema i sudjeluje u sportskim natjecanjima: a) kao član pravne osobe koja obavlja sportsku djelatnost sudjelovanja u sportskim natjecanjima i b) kao osoba koja obavlja samostalnu sportsku djelatnost sudjelovanja u sportskim natjecanjima sukladno čl. 6. st. 1 . ZoS-a. Sportaš koji u skladu s odredbom stavka 1. podstavka 1. toga članka (pod a)) sudjeluje u sportskim natjecanjima kao član pravne osobe može imati status profesionalnog sportaša ili amatera. 
Doc. dr. sc. Mijo Galiot i Silvio Čović, dipl. iur.: Odgovornost za namještanje rezultata sportskih natjecanja... Zbornik radova Pravnog fakulteta u Splitu, god. 58, 1/2021, str. 315-348

b) treneri, ${ }^{48}$ c) osobe osposobljene za rad u sportu, ${ }^{49}, \mathrm{~d}$ ) osobe koje sudjeluju u organiziranju i vođenju sportskog natjecanja (sportski sudac, sportski delegat i sportski povjerenik) ${ }^{50} \mathrm{i}$ e) menadžeri u sportu ${ }^{51}$ (članak 5. stavak 2. ZoS-a). Pravne osobe, prema članku 5. stavku 3. ZoS-a, su: a) udruge, ${ }^{52}$ b) trgovačka društva ${ }^{53}$ i c) ustanove. ${ }^{54},{ }^{55} \mathrm{U}$ pravne osobe spadaju i sportski klubovi, koji su apsolutno i osnova i condicio sine qua non bez kojega viših oblika udruživanja ne bi ni bilo. ${ }^{56} \mathrm{~S}$ tim u vezi ZoS razlikuje dva temeljna oblika sportskog kluba: a) sportski klub-udruga za natjecanje i b) sportski klub-sportsko dioničko društvo. Prema članku 27. stavku 1. ZoS-a, sportska udruga osnovana radi obavljanja sportske djelatnosti sudjelovanja u sportskom natjecanju (u daljnjem tekstu: sportski klub-udruga za natjecanje) obvezno u nazivu sadrži riječi „sportski klub“ ili ispred riječi „,klub“ naziv sporta u kojem obavlja djelatnost. ZoS, u članku 28. stavku 1., definira pojam sportski klubsportsko dioničko društvo kao sportski klub koji se osniva, djeluje i prestaje prema Zakonu o trgovačkim društvima i drugim propisima koji se primjenjuju na dionička društva, ako tim zakonom nije drugačije određeno..$^{57,58}$

48 Prema čl. 9. st. 1. ZoS-a trener u smislu toga zakona osoba je koja programira i provodi sportsku pripremu, sportsku rekreaciju i sportsku poduku.

49 Osobom osposobljenom za rad u sportu (instruktor, voditelj i sl.) smatra se osoba koja podučava građane osnovnoj tehnici pojedinog sporta ili provodi sportsku rekreaciju građana, a osposobljena je za taj rad putem ustanove za osposobljavanje kadra u sportu, s time da sportsku-rekreaciju građana može provoditi samo na temelju programa kojega je izradila osoba koja ima najmanje stručnu spremu propisanu za trenera prvostupnika (čl. 10. ZoS-a.).

50 Čl. 11. st. 1. ZoS-a propisano je da je osoba koja sudjeluje u organiziranju i vođenju sportskog natjecanja (sportski sudac, sportski delegat i sportski povjerenik), u smislu toga zakona, osoba koja ispunjava uvjete propisane pravilima odgovarajućeg nacionalnog saveza.

51 Menadžer u sportu, u smislu toga zakona, osoba je koja je prema pravilima nacionalnog saveza ovlaštena obavljati poslove posredovanja prelaska sportaša iz jednoga sportskog kluba u drugi sportski $k l u b$ (čl. 12. st. 1. ZoS-a).

52 Sportskim udrugama, u smislu toga zakona, smatraju se one udruge koje se osnivaju radi obavljanja sportskih djelatnosti propisanih tim zakonom sukladno čl. 14. st. 1. ZoS-a. Sportske udruge su i udruge iz glave V. toga zakona (čl. 14. st. 2. ZoS-a.).

53 Prema čl. 15. st. 1. ZoS-a trgovačko društvo, u smislu toga zakona, društvo je registrirano za obavljanje sportskih djelatnosti propisanih ovim Zakonom. Ako ono obavlja sportsku djelatnost sudjelovanja u sportskim natjecanjima, mora imati pravni oblik dioničkog društva (s.d.d.) sukladno tome zakonu. Na osnivanje trgovačkih društava iz stavka 1. toga članka primjenjuje se Zakon o trgovačkim društvima, osim u dijelu koji je tim zakonom drugačije određen (čl. 15. st. 2. ZoS-a).

54 Čl. 16. st. 1. i 2. ZoS-a propisano je da za trajno obavljanje sportskih djelatnosti sportske rekreacije, sportske poduke, upravljanja i održavanja sportske građevine mogu se osnivati ustanove, a one se osnivaju i djeluju u skladu s odredbama Zakona o ustanovama.

55 Detaljno o definiranju osoba ili subjekata u sustavu sporta, dvojbama i nedostacima u zakonskim definicijama v. Kačer, H., Kačer B. (2018.), op. cit. (bilj. 46), str. 39 do 69.

56 Ibid, str. 67.

57 Trgovačka društva kao oblik su postojala i prije ZoS-a, ali (što se sporta tiče) relativno rijetka u praksi. Zakon je postavio kao novotu da ono društvo koje se bavi sudjelovanjem u sportskim natjecanjima (a to ne mora svako trgovačko društvo koje se bavi sportskim djelatnostima), mora imati oblik sportskog dioničkog društva, što znači da to nije dopušteno društvima s ograničenom odgovornošću. A contrario, ako se ne bi radilo o sudjelovanju u natjecanjima, moglo bi se raditi i o društvu s ograničenom odgovornošću ili drugom obliku iz Zakona o trgovačkim društvima - tako Kačer, H., Kačer B. (2018.), op. cit. (bilj. 46), str. 69.

58 V. čl. 29. ZoS-a, kojim je uređen nastanak sportskog dioničkog društva. 
Zanimljivo je da Konvencija, za razliku od ZoS-a koji spominje osobe u sportu, u članku 6., posebno definira pojam dionik u natjecanju. Pod tim pojmom podrazumijeva svaku fizičku i pravnu osobu koja pripada jednoj od sljedećih kategorija: a) sportaš, koji znači svaka osoba ili skupina osoba koja sudjeluje u sportskim natjecanjima, b) pomoćno sportsko osoblje, koje znači svaki instruktor, trener, menadžer, agent, osoblje momčadi, dužnosnik momčadi, medicinsko ili pomoćno medicinsko osoblje koje sa sportašima koji sudjeluju u sportskim natjecanjima ili se pripremaju za sportska natjecanja radi ili ih liječi te sve druge osobe koje rade sa sportašima i c) dužnosnik, koji znači svaka osoba koja je vlasnik, imatelj udjela, rukovoditelj ili član osoblja subjekata koji organiziraju i promiču sportska natjecanja, kao i suci, članovi žirija i sve druge akreditirane osobe, pri čemu su izrazom obuhvaćeni i rukovoditelji i osoblje međunarodnih sportskih organizacija ili, prema potrebi, drugih nadležnih sportskih organizacija koje priznaju predmetno natjecanje.

Pojam namještanje sportskih natjecanja nije pobliže definiran u hrvatskom zakonodavstvu. Međutim, Konvencija, u svom prvom poglavlju, ${ }^{59}$ i za njezine potrebe i svrhu ${ }^{60}{ }^{\text {spominje pojam ,,manipulacija }}{ }^{61},{ }^{62}$ sportskim natjecanjima koji je, mišljenja smo, usko povezan s namještanjem rezultata sportskih natjecanja. U članku 3. stavku 4., pojam manipulacija sportskim natjecanjima definiran je kao namjeran dogovor, čin ili propust s ciljem nepropisne izmjene rezultata ili tijeka sportskog natjecanja kako bi se djelomično ili u cijelosti dokinula nepredvidljiva priroda navedenog sportskog natjecanja s ciljem dobivanja neprimjerene prednosti za sebe ili za druge.

U tom kontekstu valja navesti i pobliži sadržaj pojma sportsko klađenje, koji je, pokazala je praksa, imanentan namještanjima i manipulacijama rezultata natjecanja. Konvencija, u članku 3. stavku 5., definira i sportsko klađenje kao stavljanje uloga novčane vrijednosti u očekivanju nagrade novčane vrijednosti uvjetovane budućim i neizvjesnim događajem povezanim sa sportskim natjecanjem. Osim toga ona razlikuje tri temeljne vrste sportskog klađenja: a) nezakonito sportsko klađenje, b) neregularno sportsko klađenje i c) sumnjivo sportsko klađenje. Nezakonito sportsko klađenje podrazumijeva svaku vrstu aktivnosti sportskog klađenja koja nije dopuštena i svaki priređivač aktivnosti sportskog klađenja koji se njome ne smije baviti u skladu s mjerodavnim pravom jurisdikcije u kojoj se nalazi potrošač. Neregularno sportsko klađenje znači svaku aktivnost sportskog klađenja koja nije u skladu s uobičajenim ili očekivanim pojavama na predmetnom tržištu, ili je povezana s klađenjem na sportsko natjecanje čiji tijek ima neuobičajene karakteristike. Sumnjivo sportsko klađenje znači svaku aktivnost sportskog klađenja koja, prema

59 Poglavlje I. - Svrha, vodeća načela, definicije.

${ }^{60}$ Prema čl. 1. stavku 1. svrha Konvencije jest suzbijanje manipulacije športskim natjecanjima radi zaštite integriteta športa i športske etike u skladu s načelom neovisnosti športa.

61 Lat. manipulatio.

${ }^{62}$ Manipulacija znači vješto, stručno rukovanje ili upravljanje nečim; pravljenje poslovnih smicalica; dodirivanje ili prevlačenje rukom preko živčano oboljelog tijela - tako Anić, Š., Klaić, N., Domović, Ž., Rječnik stranih riječi, Sani-plus, Zagreb, 2002., str. 850. 
Doc. dr. sc. Mijo Galiot i Silvio Čović, dipl. iur.: Odgovornost za namještanje rezultata sportskih natjecanja... Zbornik radova Pravnog fakulteta u Splitu, god. 58, 1/2021, str. 315-348

pouzdanim i dosljednim dokazima, izgleda povezana s manipulacijom sportskim natjecanjem za koje se klađenje nudi.

\subsubsection{Službena dužnost $t^{63}$}

Službena dužnost, kao pojam, u hrvatskom zakonodavstvu, nije definirana. No, analizom različitih doktrinarnih razmišljanja, moglo bi se otežano doći do neizvjesnog zaključka što bi ta dužnost obuhvaćala.

Na općenitoj i apstrahiranoj razini, Tulićct ${ }^{4}$ službenu dužnost definira kao zbiljski odražaj države. Smatra da u svojoj raznolikosti ona predstavlja sistem unutar kojeg počiva sigurnost pravnog poretka kao i društva u cjelini.

$D_{r m i c}{ }^{65}$ definira službenu dužnost kroz prizmu i pojam službeničkog odnosa kako je definiran u članku 1. ZDS-a. Službenički odnos, prema uređenju ZDS-a, definiran je kao radni odnos između državnog službenika kao radnika i države kao poslodavca. Unutar tog odnosa, radnopravni status državnih službenika ${ }^{66}$ predstavlja ukupnost njegovih prava i dužnosti utvrđenih propisom. ${ }^{67}$ Možemo zaključiti da on službenu dužnost veže uz pojam državnog službenika i obavljanje državne službe.

Prema Derenčinoviću ${ }^{68}$ osnovno obilježje kaznenih djela protiv službene dužnosti ugrožavanje je nesmetanog funkcioniranja službi od javnog interesa. On, uz Dragičević Prtenjača, ${ }^{69}$ smatra valjanim razmotriti da se naziv glave dvadeset osme „,novelira“, tako da sada glasi „Kaznena djela protiv javne službe i javnih ovlasti“, kako bi potpunije odgovarala opisima kaznenih djela koji su u njoj predviđeni. Podredno, ako se službena dužnost (odnosno ono što bi se imalo razumjeti pod tim pojmom) ne bi moglo podvesti pod pojam ,javnih ovlasti“, predlaže da se glava KZ-a nazove „Kaznena djela protiv državne $i$ javne službe $i$ javnih ovlasti“. I s jednom is drugom konstatacijom u potpunosti smo suglasni i smatramo ih logičnim i opravdanim zahtjevima de lege ferenda.

Polazeći od definicija pojma javna služba, kako je definiran u Republici Hrvatskoj, pojam službene dužnosti mogli bismo definirati dvojako. Prvo, pod njim bismo mogli razumjeti dužnost pripadnika, dužnosnika i službenika zaposlenih u državnim i drugim javnim tijelima. Drugo, mogli bismo je definirati kao dužnosti

63 Ovo poglavlje s neznatnim izmjenama čini navođenje dijela doktorske disertacije autora Galiot (2018.), op. cit. (bilj. 24), str. 177 i 178.

${ }^{64}$ Tulić, A., Krivična djela protiv službene dužnosti, str. 18 - dostupno na: www.pravnadatoteka,hr/ pdf(Krivična\%20djela\%20službene\%20dužnosti.pdf (7. III. 2017).

65 Drmić, A., „Vrste povreda službene dužnosti i disciplinske sankcije“, Hrvatska javna uprava, Zagreb, 2010., str. 771-797.

66 Tko su državni službenici v. čl. 3. i 4. Zakon o državnim službenicima (NN, br. 92/05, 140/05, 142/06, 77/07, 107/07, 27/08, 34/11, 49/11, 150/11, 34/12, 37/13, 38/13, 1/15, 138/15, 102/15, 61/17, 70/19 i 98/19).

67 Borković, I., Službeničko pravo, Informator, 1999., str. 107.

68 Derenčinović, D., Cvitanović, L., Munivrana V., Turković, K., Posebni dio kaznenog prava, (ur.) Derenčinović, D., Pravni fakultet Sveučilišta u Zagrebu, Zagreb, 2013., str. 226.

69 Dragičević Prtenjača, M., Kaznenopravni aspekti pasivnog podmićivanja u hrvatskom pravnom sustavu, doktorska disertacija, Zagreb, 2014., str. 391 (doktorska disertacija neposredno predana autorima). 
Doc. dr. sc. Mijo Galiot i Silvio Čović, dipl. iur.: Odgovornost za namještanje rezultata sportskih natjecanja... Zbornik radova Pravnog fakulteta u Splitu, god. 58, 1/2021, str. 315-348

zaposlenika javnopravnih tijela u čiji djelokrug poslova spadaju društvene djelatnosti (obrazovanje, znanost, zdravstvo, socijalna i mirovinska skrb), a koje po svojoj prirodi nemaju komercijalni karakter.

$\mathrm{S}$ aspekta pojma javne službe kako je definirana u međunarodnoj doktrini, pod „službenom dužnosti“" mogli bismo shvatiti dužnosti koje se obavljaju u javnoj $i$ svakoj drugoj službi koja se obavlja u interesu zajednice. Dakle, tu bi se radilo i o „dužnostima“ "koje se, osim u javnoj službi, obavljaju i unutar službi u čiji djelokrug ne spadaju samo društvene djelatnosti već $i$ djelatnosti, koje, po svojoj prirodi, imaju gospodarski (komercijalni) karakter.

Ako uzmemo u obzir samo definiciju pojma javni službenik, autor smatra da bi se pod službenom dužnosti moglo razumjeti dužnost osoba koje u svojstvu službenika obavljaju poslove u državnim tijelima, ali i u tijelima jedinice lokalne samouprave $i$ uprave, kao i odgovarajućim javnim službama, odnosno pravnim osobama koje djeluju na temelju javnih ovlasti. A ako bismo cijenili samo definiciju pojma državni službenik koji je uži od javnog službenika, službena bi dužnost obuhvaćala dužnost osoba koje su zaposlene u državnim tijelima.

\subsubsection{O pojmu odgovorna osoba prema $K Z-u$}

Iako bića kaznenih djela primanja mita i davanja mita u svojim stipulacijama sadrže pojmove službena i odgovorna osoba, s aspekta analiziranja odgovornosti za počinjenje navedenih kaznenih djela s ciljem manipulacije sportskih natjecanja, bitno je u ovom dijelu rada pobliže razmotriti sadržaj samo pojma odgovorne osobe. ${ }^{70}$

KZ, u članku 87. stavku 6., odgovornu osobu definira kao fizičku osobu koja vodi poslove pravne osobe ili joj je izričito ili stvarno povjereno obavljanje poslova $i z$ područja djelovanja pravne osobe ili državnih tijela ili tijela jedinice lokalne $i$ područne (regionalne) samouprave. $.^{71},{ }^{72}$ Valja uvidjeti da KZ, za razliku od svoga prethodnika, ${ }^{73}$ ne daje definiciju pojma pravne osobe, što predstavlja legislativni „korak unatrag“ u regulaciji kaznenog materijalnog prava. ${ }^{74}$ Pozitivno pravna definicija odgovorne osobe, u odnosu na definiranje službene osobe, postavljena je mnogo apstraktnije, što je dovelo do učestalih dvojbi u teoriji i sudskoj kaznenoj

70 Podrobno o pojmu službene osobe v. Galiot (2018.), op. cit. (bilj. 24), str. 184 do 189.

71 Usp. s čl. 4. Zakona o odgovornosti pravnih osoba za kaznena djela (NN, br. 151/03, 110/07, 45/11 i 143/12). Prema tom članku pod odgovornom osobom podrazumijeva se fizička osoba koja vodi poslove pravne osobe ili joj je povjereno obavljanje poslova iz područja djelovanja pravne osobe.

72 Usp. i s čl. 61. st. 1. Prekršajnog zakona (NN, br. 107/07, 39/13, 157/13, 110/15, 70/17 i 118/18), prema kojem je odgovorna osoba u smislu toga zakona fizička osoba koja vodi poslove pravne osobe ili joj je povjereno obavljanje određenih poslova iz područja djelovanja pravne osobe.

73 Prema čl. 89. st. 6. Kaznenog zakona (NN, br. 110/97, 27/98, 50/00, 129/00, 51/01, 111/03, 190/03, 105/04, 84/05, 71/06, 110/07, 152/08 i 57/11, u daljnjem tekstu: KZ/97) pravna osoba u smislu toga zakona je trgovačko društvo, fond, ustanova, politička i društvena organizacija i udruženja građana, jedinica lokalne samouprave i uprave, jedinica lokalne samouprave te druga pravna osoba koja u okvirima svog redovnog poslovanja stalno ili povremeno stvara ili pribavlja sredstva i njima raspolaže.

74 Galiot (2018.), op. cit. (bilj. 24), str. 190. 
praksi po pitanju tko bi ulazio u krug takvih osoba. ${ }^{75} \mathrm{~S}$ druge strane, ona je u određenom segmentu i restriktivna, s obzirom na to da isključuje osobe u pravnim tvorevinama koje nemaju status pravne osobe.$^{76}$ Budući da pojam odgovorne osobe, kako je određen u članku 87. stavku 6. KZ-a, obuhvaća širok i netransparentan krug osoba, u praksi su se pojavile dvojbe pri tumačenju i primjeni te odredbe u kaznenim postupcima koji su se vodili zbog počinjenja kaznenih djela primanja mita i davanja mita s ciljem namještanja rezultata sportskih natjecanja.

„Vrhovni sud je po ovom pitanju, tumačeći članak 89. stavak 7. KZ/97-a, zauzeo sljedeća pravna shvaćanja: a) opunomoćenik, potpisujući inkriminirani ugovor čiji je sadržaj bio pripremljen, na temelju punomoći odgovorne osobe u trgovačkom društvu, nije stekao svojstvo odgovorne osobe u trgovačkom društvu, jer mu s punomoći nije bio povjeren određeni djelokrug poslova iz područja djelovanja pravne osobe, odnosno koji se odnosi na izvršenje zakonskih propisa ili nekog drugog općeg akta o upravljanju imovinom trgovačkog društva, ${ }^{77}$ b) $z a$ utvrđenje pojma odgovorne osobe odlučno je utvrđenje stvarnog kruga povjerenih poslova iz područja djelovanja pravne osobe ${ }^{78} \mathrm{c}$ ) odgovorna osoba može biti samo ona osoba kojoj je u pravnoj osobi bilo povjereno obavljanje administrativnih $i$ knjigovodstvenih poslova, pri čemu su za utvrđenje ovog pojma pravno relevantne ovlasti koje bi određenu osobu činile odgovornom osobom u pravnoj osobi, a ne $i$ opis poslova koje je (stvarno) obavljao, ${ }^{79} \mathrm{~d}$ ) direktor trgovačkog društva ima se smatrati odgovornom osobom u smislu članka 89. stavka 7. KZ/97-a ${ }^{80} \mathrm{e}$ ) predsjednik nadzornog odbora trgovačkog društva može se podvesti pod službenom osobom ${ }^{81}$ te f) osnivaču trgovačkog društva, koji nema status uprave društva, nedostaje svojstvo odgovorne osobe u tom društvu, budući da on niti je zadužen, a niti mu je povjereno obavljanje poslova društva iz područja djelovanja pravne osobe, te stoga što je obavljanje tih poslova u isključivoj nadležnosti uprave, tj. direktora društva koji je dužan poduzimati prema svima potrebne pravne radnje radi zaštite interesa društva odnosno ostvarivanja cilja zbog kojeg je osnovano. ${ }^{82}$

Za bolje razumijevanje pojma odgovorne osobe u hrvatskom kaznenom pravu i praksi valja skrenuti pozornost i na neka aktualna pitanja i odgovore koje je iznio

75 Ibidem.

76 V. čl. 148. st. 3. Zakon o trgovačkim društvima (NN, br. 111/93, 34/99, 121/99, 52/00, 118/03, 107/07, 146/08, 137/09, 111/12, 125/11, 68/13, 110/15 i 40/19).

77 Iz presude broj IV Kž-14/06-3 od 12. travnja 2006., dostupna na: https://sudskapraksa.csp.vsrh. hr/ (14. V. 2020.).

78 Iz presude broj III Kr-194/08-3 od 3. ožujka 2009., dostupna na: https://sudskapraksa.csp.vsrh.hr/ (14. V. 2020.).

79 Iz presude broj IV Kž-107/16-2 od 12. prosinca 2006., dostupna na: https://sudskapraksa.csp.vsrh. hr/ (14. V. 2020.).

${ }^{80}$ Iz presude broj I Kž-652/13-4 od 26. studenoga 2013., dostupna na: https://sudskapraksa.csp.vsrh. hr/ (14. V. 2020.).

81 Iz presude broj IV Kž-19/05-3 od 19. travnja 2005., dostupna na: https://sudskapraksa.csp.vsrh. hr/ (14. V. 2020.).

${ }^{82}$ Iz presude broj I Kž-317/04-3 od 7. ožujka 2006., dostupna na: https://sudskapraksa.csp.vsrh.hr/ (14. V. 2020.). 
Derenčinović. ${ }^{83}$ Prvo, na pitanje mora li odgovorna osoba uvijek biti pojedinačno određena fizička osoba u pravnoj osobi ili se u većim pravnim osobama odgovornom osobom mogu smatrati i tijela odlučivanja (npr. uprava u dioničkom društvu), zaključuje da $i$ kod pravnih osoba kod kojih odlučivanje nije „u rukama“ pojedinaca već je povjereno kolegijalnom tijelu, uvijek je potrebno utvrditi pojedinačno odgovornu fizičku osobu ${ }^{84}$ Drugo, odgovorna osoba ne mora (nužno) uvijek biti osoba koja je, kao odgovorna, određena zakonom, aktom o osnivanju ili odlukom tijela upravljanja pravne osobe, smatrajući da je česta praksa da pravne osobe u aktu o osnivanju odrede kao odgovornu onu fizičku osobu, koja, zbog prirode posla što ga obavlja, ne može biti odgovorna osoba, i da se formalnim određivanjem odgovorne osobe zapravo ciljano prikriva prava odgovorna osoba pravne osobe. ${ }^{85} \mathrm{I}$, treće, odgovorna osoba ne mora nužno biti u radnom odnosu u pravnoj osobi, iako je to u praksi najčešće tako. ${ }^{86,87}$

\subsection{Europska pravna stečevina o suzbijanju manipulacija sportskim natjecanjima}

Lisabonskim ugovorom ${ }^{88}$ Europska unija (skraćeno: EU) prvi put je dobila nadležnost u području sporta. ${ }^{89}$ Članak 165 . TFEU-a ${ }^{90}$ predstavlja novi korak u razvoju sportske problematike u Uniji utoliko što izrijekom spominje sport kao područje EU-djelovanja. ${ }^{91}$ Najvažnija osobina toga članka jest da za EU stvara novu pravnu osnovu koja joj dopušta usvajanje mjera za razvoj europske dimenzije sporta. ${ }^{92}$ Sport je jedno od onih područja na kojima cee Unija imati nadležnost realizirati akcije podrške, suradnje i nadopune akcija država članica ${ }^{93}$ Riječ je o tzv. soft-competence prema kojoj EU može djelovati u skladu s ordiniranom legislativnom procedurom uz isključenje bilo kakvog usklađivanja zakona i propisa

83 Derenčinović, D., „Sedam pitanja u vezi s utvrđivanjem pojma „odgovorne osobe“ u hrvatskom kaznenom pravu i sudskoj praksi“, Pravo i porezi, Zagreb, br. 9., 2003., str. 3-9.

84 Derenčinović (2003.), op. cit. (bilj. 83.), str. 4.

85 Ibidem.

86 Ibid, str. 6.

87 Oba pasusa s neznatnim izmjenama čini navođenje dijela doktorske disertacije autora Galiot (2018.), op. cit. (bilj. 24), str. 193 i 194.

${ }_{88}$ Lisabonski ugovor, ratificiran 2009., izmijenio je dotadašnje Osnivačke ugovore, unoseći amandmane na postojeći tekst Ugovora. Ugovor o Europskoj uniji (UEU) i dalje nosi isti naziv, ali je Ugovor o Europskoj zajednici preimenovan u Ugovor o funkcioniranju Europske unije (TFEU).

89 Bačić, Bačić (2011.), op. cit. (bilj. 1), str. 693.

90 Prema čl. 165. st. 1. i 2. TFEU-a (bivši čl. 149. UEZ-a) Unija doprinosi promidžbi europskog sporta, vodeći pritom računa o specifičnoj prirodi sporta, njegovim strukturama koje se temelje na dobrovoljnim aktivnostima te njegovoj društvenoj i obrazovnoj ulozi. Cilj djelovanja Unije jest i razvijanje europske dimenzije u sportu promicanjem pravednosti i otvorenosti na sportskim natjecanjima i suradnje među tijelima odgovornima za sport te zaštitom tjelesnog i moralnog integriteta sportaša i sportašica, osobito najmlađih sportaša i sportašica.

91 Ibid, str. 689.

92 Ibidem.

93 Ibidem. 
država članica, što znači, drugim riječima, da ona ne može harmonizirati sportske propise širom Europe i da je prednost na strani nacionalne samoregulacije. ${ }^{94}$

Vijeće Europe i druge međunarodne organizacije donijele su čitav niz bitnih pravnih akata u cilju suzbijanja (koruptivnih) namještanja rezultata sportskih natjecanja, ${ }^{95}$ među kojima je najrecentnija Konvencija Vijeća Europe o manipulaciji športskim natjecanjima. ${ }^{96}$ Ona je donesena upravo na podlozi ponajprije kreiranja nove zakonodavne nadležnosti, kako je ona predviđena navedenim člankom 165. TFEU-a. ${ }^{97},{ }^{98}$

Svrha Konvencije jest suzbijanje manipulacije športskim natjecanjima radi zaštite integriteta sporta i sportske etike u skladu s načelom neovisnosti sporta (članak 1.), a njezini glavni ciljevi su: a) sprečavanje, otkrivanje i kažnjavanje nacionalnih i transnacionalnih manipulacija nacionalnim i međunarodnim sportskim natjecanjima $\mathrm{i}$ b) promicanje nacionalne i međunarodne suradnje među tijelima javne vlasti, kao i s organizacijama uključenima u sport i sportsko klađenje, u borbi protiv manipulacije sportskim natjecanjima (članak 2.). Vodeća načela u borbi protiv manipulacije sportskim natjecanjima, prema članku 2., jesu načela: a) ljudskih prava, b) zakonitosti, c) proporcionalnosti i d) zaštite privatnosti i osobnih podataka. U daljnjem dijelu istaknut će se neke bitne odredbe Konvencije s obzirom na predmet istraživanja.

Tako Konvencija, u poglavlju III., člancima 12. do 14. uspostavlja obvezu razmjene informacija povezanih s manipulacijom sportskih natjecanja.

S aspekta kažnjavanja davatelja i primatelja mita u kontekstu namještanja rezultata sportskih natjecanja osobito je bitno poglavlje IV. Konvencije. ${ }^{99}$ Clankom 15. propisano je da svaka stranka osigurava da se njezinim unutarnjim pravom kao kazneno djelo sankcionira manipulacija sportskim natjecanjima kada ona uključuje prisilu, korupciju ili prijevaru, kako su definirane u njezinom unutarnjem pravu. Valja primijetiti da Konvencija nameće obvezu tzv. obligatornog kažnjavanja za počinjenje kaznenog djela koje uključuje manipulaciju sportskim natjecanjima samo u situaciji ako je riječ o: a) prisili, b) prijevari i c) koruptivnim radnjama. ${ }^{100}$

U poglavlju V. Konvencije određuje se nadležnost, kazneni postupak i provedbene mjere za kaznena djela iz članka 15. do 17., a poglavlje VI. uređuje sankcije i

94 Ibid., str. 693 i 694.

95 U definiranju standarda i mjera u borbi protiv korupcije najvažnijim međunarodnim dokumentima smatraju se Konvencija Ujedinjenih naroda protiv korupcije (NN-MU, br. 14/02 i 11/04) i Kaznenopravna konvencija o korupciji Vijeća Europe uz Dodatni protokol (NN - MU, br. 11/00 i 3/05), a bitno mjesto zauzima i Okvirna odluka Vijeća Europe o borbi protiv korupcije u privatnom sektoru (SL L 192/54, objavljeno 31. srpnja 2003.) koja je donesena na razini EU-a.

96 Usp. s Primorac, D., ,Suzbijanje manipulacije sportskim natjecanjima prema Konvenciji Vijeća Europe Cets broj 215“, Zbornik radova Pravnog fakulteta u Splitu, 2/2020., str. 353.

97 Pravna osnova za donošenje Konvencije sadržana i u čl. 16., 82. st. 1. i 2., čl. 83. st. 1., čl. 114 i čl. 207.

98 O nizu drugih dokumenata koji su prethodili njezinu donošenju v. Primorac (2020.), op. cit. (bilj. 96), str. 354 i 355.

99 Poglavlje IV. - Kazneno materijalno pravo i suradnja u pogledu provedbe (čl. 15. do 18.).

100 Usp. Primorac (2020.), op. cit. (bilj. 96), str. 362. 
mjere prema počiniteljima kaznenih djela koji su obuhvaćeni Konvencijom. U potonjem poglavlju Konvencija odvojeno uređuje: a) kaznenopravne sankcije za fizičke osobe, ${ }^{101}$ b) sankcije za pravne osobe, c) upravne sankcije ${ }^{102}$ i d) privremeno oduzimanje (imovinske koristi koja je ostvarena kaznenim djelima ili imovine koja odgovara toj koristi, ali i oduzimanje predmeta, dokumenata i drugih instrumenata koji se upotrebljavaju ili su namijenjeni da ih se upotrebljava za počinjenje kaznenih djela iz članka 15. do 17. Konvencije). ${ }^{103,104}$

Svaka stranka donosi zakonodavne i druge odgovarajuće mjere da bi namjerno pomaganje i poticanje na bilo koje od kaznenih djela iz članka 15. proglasila kaznenim djelima prema unutarnjem pravu (članak 17.). Može se zaključiti da Konvencija potiče države potpisnice na sankcioniranje ne samo (su)počinitelja, nego i sudionika (poticatelja i pomagatelja) kaznenih djela iz članka 15. Konvencije. ${ }^{105}$

Konvencija, u poglavlju VII. Međunarodna suradnja u sudskim i drugim stvarima, predviđa i potiče stranke da poduzimaju mjere: a) u pogledu međunarodne suradnje $\mathrm{u}$ kaznenim stvarima (članak 26.), b) ostale mjere međunarodne suradnje u pogledu prevencije (članak 27.) i c) međunarodnu suradnju s međunarodnim sportskim organizacijama (članak 28.). ${ }^{106}$

Važnost donošenja i primjene Konvencije u nacionalnim je zakonodavstvima nemjerljiva i ona predstavlja značajan i pozitivan korak naprijed u borbi protiv manipulacije sportskim natjecanjima te u očuvanju integriteta sporta. ${ }^{107}$

\subsection{Hrvatsko pozitivno pravno uređenje}

U tumačenju i primjeni različitih grana prava te razmatrajući njihov (su)odnos uobičajena je teza o odnosu općeg i posebnog, ali ta je teza ipak (kao isključiva, kao ona koja ne trpi iznimke) sve manje primjenjiva na mnoge slučajeve, pa tako i

101 Prema čl. 22. svaka stranka poduzima potrebne zakonodavne ili druge mjere kako bi osigurala da su kaznena djela iz članaka od 15. do 17. ove Konvencije, kada su ih počinile fizičke osobe, kažnjiva učinkovitim, proporcionalnim i odvraćajućim sankcijama, uključujući novčane kazne, uzimajući u obzir težinu kaznenih djela. Te sankcije uključuju kazne koje za posljedicu imaju lišavanje slobode koje može dovesti do izručenja, kako je određeno unutarnjim pravom.

102 Čl. 24. Konvencije propisano je da svaka stranka donosi, kada je to potrebno, u odnosu na djela koja su kažnjiva prema njezinu unutarnjem pravu, zakonodavne i druge odgovarajuće mjere za kažnjavanje kršenja utvrđenih u skladu s ovom Konvencijom, primjenom učinkovitih, razmjernih i odvraćajućih sankcija i mjera u postupcima koje pokreću upravna tijela, kada odluka može dovesti do postupka pred nadležnim sudom.

103 V. čl. 25. Privremeno oduzimanje.

104 Podrobno o oduzimanju imovinske koristi u situacijama aktivnog i pasivnog podmićivanja v. Galiot, M., „Oduzimanje imovinske koristi u kontekstu međunarodne pravne stečevine i suzbijanja podmićivanja“, Zbornik Pravnog fakulteta Sveučilišta u Rijeci, 1/2017, str. 547-572.

105 V. čl. 18., koji uređuje tzv. korporativnu odgovornost, odnosno odgovornost pravnih osoba za kaznena djela iz članka 15. do 17. Konvencije. Takva odgovornost ne dovodi u pitanje kaznenu odgovornost fizičkih osoba koje su počinile to kazneno djelo prema čl. 18. st. 4. Konvencije.

106 Poglavljem VIII. (čl. 29. do 31.) uređeno je praćenje provedbe Konvencije, a poglavlje IX. (čl. 32. do 41.) uključuje završne odredbe.

107 Primorac (2020.), op. cit. (bilj. 96), str. 371. 
na sportsko pravo. ${ }^{108}$ Naime, sve je jasnije da je istodobno riječ o dva međusobno suprotstavljena procesa ili činjenice - sportsko je pravo lex specialis glede sporta u odnosu na sve druge grane prava i to se načelno i ne spori, ali je isto tako točno da glede mnogo toga postoji i obrnuta situacija. ${ }^{109}$ Primjerice, ako je riječ o kaznenopravnoj odgovornosti za namještanje rezultata sportskih natjecanja, kazneno materijalno zakonodavstvo ima značenje specijalnog propisa u odnosu na norme sportskog prava, koje imaju status lex generalis. Polazeći od navedenoga, u nastavku će se izložiti hrvatsko pozitivnopravno uređenje kaznene odgovornosti zbog kaznenih djela primanja mita i davanja mita koja su počinjena s ciljem namještanja rezultata odnosno manipulacije sportskim natjecanjima.

Temeljni pravni izvor u pogledu sportskog prava, pa i glede namještanja rezultata sportskih natjecanja, jest Ustav Republike Hrvatske. ${ }^{110}$, ${ }^{111}$ Prema članku 68. stavku 5. Ustava, država potiče i pomaže skrb o sportu. Vezano za predmet istraživanja osobito su bitne i odredbe Ustava, kojima su uređena neka temeljna procesna i materijalna načela kaznenog prava. Ustav, osim stožernog načela prava na pravično suđenje, sadrži i niz drugih pojedinačnih materijalnih i postupovnih jamstava okrivljenika koja su sadržana u člancima 24., 25., 28., 29. stavka 2. i članka 31. Ustava. ${ }^{112}$ Razlikuju se opći i posebni elementi pojma pravičnog kaznenog postupka. ${ }^{113} \mathrm{U}$ opće elemente ulazila bi prava stranke: a) biti nazočna radnjama u postupku te saslušana prije donošenja odluke, b) da u postupku poduzima sve radnje koje može poduzimati protivnik - jednakost oružja, c) da se, u načelu, sudske odluke ne smiju temeljiti na nezakonitim dokazima i d) da ishodi obrazloženu sudsku odluku. ${ }^{114} \mathrm{U}$ posebne elemente vezane uz kazneni progon ulazili bi: a) pretpostavka okrivljenikove nedužnosti i b) posebna jamstva okrivljenikove obrane - donji prag, minimum jamstava zaštite okrivljenika u sporu s državom. ${ }^{115}$

U članku 31. stavku 1. Ustava, u okviru načela zakonitosti, uređena su dva temeljna načela kaznenog materijalnog prava: nullum crimen sine lege (nema kaznenog djela bez zakona) i nulla poena sine lege (nema kazne bez kaznenog zakona). Prema navedenoj načelnoj „,definiciji“ ustavotvorca nitko ne može biti kažnjen za djelo koje prije nego je počinjeno nije bilo utvrđeno zakonom ili međunarodnim pravom kao kazneno djelo, niti mu se može izreći kazna koja nije bila određena zakonom. U stavku 2. toga članka sadržano je načelo ne bis in idem, prema kojem se, u pravilu, nikome ne može ponovno suditi niti ga se može kazniti u kaznenom postupku za

108 Kačer, Kačer, Čizmić (2018.), op. cit. (bilj. 14), str. 17.

109 Ibidem

110 Ustav Republike Hrvatske (NN, br. 56/90, 135/97, 8/98 - pročišćeni tekst, 113/00, 124/00 pročišćeni tekst, 28/01, 41/01, 55/01 - ispravak, 76/10, 85/10 - pročišćeni tekst i 5/14, u daljnjem tekstu: Ustav).

111 Usp. Kačer, H., Perkušić, A., Ivančević-Kačer, B., „Postoji li u Republici Hrvatskoj (kvalitetno) sportsko pravo“, Zbornik radova Pravnog fakulteta u Splitu, 4/2012, str. 728.

112 V. čl. 24., 25., 28., 29. st. 2. i čl. 31. Ustava.

113 Carić, M., „Pojam načela pravičnog postupka pred kaznenim sudom“, Zbornik radova pravnog fakulteta u Splitu, Split, 2006., str. 61 do 70.

114 Ibid., str. 61 do 65.

115 Carić (2006.), op. cit. (bilj. 113.), str. 66-70. 
Doc. dr. sc. Mijo Galiot i Silvio Čović, dipl. iur.: Odgovornost za namještanje rezultata sportskih natjecanja... Zbornik radova Pravnog fakulteta u Splitu, god. 58, 1/2021, str. 315-348

kazneno djelo za koje je već pravomoćno oslobođen ili osuđen u skladu sa zakonom. Ono se tradicionalno povezuje s pravom na pravično suđenje. ${ }^{116}$ Riječ je o pravu koje se prema članku 4. stavku 3. Protokola 7. Konvencije ne može derogirati na temelju članka 15. Konvencije u vrijeme rata ili drugog izvanrednog stanja koje ugrožava opstanak naroda, čime se svrstava u kategoriju nederogabilnih konvencijskih prava, zajedno s pravom na život, zabranom mučenja, zabranom ropstva i načelom legaliteta. ${ }^{117,118}$ To pravo je odraz javnog interesa da pravomoćne sudske presude donesene u kaznenom postupku (res iudicata) budu neosporive, u skladu sa zahtjevima pravne sigurnosti. ${ }^{119}$ Prema judikaturi Ustavnog suda ono vrijedi ako je istoj osobi za isto djelo već pravomoćno presuđeno meritornom odlukom, dakle osuđujućom ili oslobađajućom presudom kojom je odlučeno o krivnji. ${ }^{120}$

Promatrano na zakonskoj razini, ključni pravni izvori vezano za kaznenu odgovornost za počinjenje klasičnih djela podmićivanja radi manipulacije sportskim natjecanjima, jesu Kazneni zakon (skraćeno: KZ) i Zakon o sportu (skraćeno: $\mathrm{ZoS}) .{ }^{121}$

ZoS uređuje: sustav sporta i sportske djelatnosti, stručne poslove u sportu, sportska natjecanja, fnanciranje sporta, nadzor i ostala pitanja od značaja za sport. ${ }^{122}$ Povezano s ciljem istraživanja ovoga rada osobito su bitne opće odredbe ZoS-a te njegovo poglavlje koje uređuje sudionike, fizičke i pravne osobe u sustavu sporta i sportske djelatnosti. ${ }^{123}$, ${ }^{124}$ To se odnosi i na odredbe sadržane u Poglavlju VII. Sportska natjecanja. ${ }^{125}$

Člankom 61. stavkom 1. ZoS-a propisano je da načela i osnovne elemente sustava sportskih natjecanja u Republici Hrvatskoj te uvjete sudjelovanja hrvatskih sportaša i sportskih klubova na međunarodnim sportskim natjecanjima utvrđuje Hrvatski olimpijski odbor (skraćeno: HOO), Hrvatski paraolimpijski odbor (skraćeno: HPO) odnosno Hrvatski sportski savez gluhih (skraćeno: HSSG). Sustav, uvjete i organizaciju sportskih natjecanja u pojedinom sportu utvrđuje nacionalni sportski savez u skladu s načelima i elementima sustava koje je utvrdio HOO, HPO odnosno

116 Ivičević Karas, E., Kos, D., „Primjena načela ne bis in idem u hrvatskom kaznenom pravu“, Hrvatski ljetopis za kazneno pravo i praksu, Zagreb, 2012., str. 556.

117 Ibidem.

118 O dopuštenim iznimkama od načela ne bis in idem i utjecaju judikature Europskog suda za ljudska prava na hrvatsko pravo i praksu v. Ibid., str. 557 do 560.

119 Renucci, J. F., Droit europeen des droits de l'homme, Contentieux europeen, L. G. D. J., Paris, 2010., str. 327.

120 Ivičević Karas, Kos (2012.), op. cit. (bilj. 116.), str. 578.

121 Postoji i niz drugih propisa kojima je uređeno ponajprije sportsko pravo, ali i niz drugih propisa čiji cilj pri donošenju nije bilo uređivanje te grane prava, ali se primjenjuju i na području sporta. Oni nisu predmet analiziranja ovoga rada, s obzirom na to da je predmet istraživanja ograničen samo na kaznenu odgovornost za počinjenje koruptivnih kaznenih djela aktivnog i pasivnog podmićivanja (i to samo klasičnih oblika davanja i primanja mita), a koja su povezana s namještanjem rezultata sportskih natjecanja.

122 V. čl. 1. st. 1. ZoS-a.

123 V. Poglavlje IV. Sustav sporta i sportske djelatnosti.

124 O pojmu športskog natjecanja i njegovim sudionicima v. 2.1.1. ovoga rada.

125 Članci 61. do 64. ZoS-a. 
HSSG, prema pravilima sporta i normama međunarodnih sportskih udruženja (članak 61. stavak 2. ZoS-a). Nacionalni sportski savez organizira i vodi sportska natjecanja, a vođenje i organiziranje natjecanja može povjeriti svojoj članici ili drugoj pravnoj osobi registriranoj za obavljanje sportske djelatnosti u skladu sa člankom 61. stavkom 6. ZoS-a.

Može se primijetiti da ZoS, na vrlo općenitoj razini, uređuje sportsko natjecanje i način njegova odvijanja. Posljedično tomu, osim zakona, izvor sportskog prava, pa i $\mathrm{u}$ istraživanju razmatrane kaznene odgovornosti, brojni su podzakonski propisi koji se donose u obliku pravilnika, uredbi ali i brojna pravila igre, propozicije natjecanja, stegovnici, etički kodeksi i slično. ${ }^{126}$ Naime, s obzirom na to da se značajan dio sportske djelatnosti oslanja na rad brojnih pravnih osoba u sportu (primjerice, sportski savezi, sportske ustanove, sportska trgovačka društva, sportske udruge, sportske zajednice i sl.), dio sportske djelatnosti uređuje se i općim aktima tih pravnih osoba (tzv. autonomno pravo). ${ }^{127}$ Statuti i drugi opći akti pravnih osoba nisu opći izvor sportskog postupovnog prava kao što je to, primjerice, propis (zakon) koji obvezuje sve sudionike pravnog prometa, ali on je za pojedine subjekte, kako za njihove unutarnje odnose tako i odnose prema van, obvezatan akt koji je za njih u velikoj mjeri izvor prava, obveza i odgovornosti. ${ }^{128}$ Opći akti pravnih osoba, u širem smislu riječi, autonomni su i samostalni akti jer, u pravilu, ne podliježu (prethodnom) odobrenju nikakvih tijela izvana, no, oni jasno moraju biti u skladu s ustavom i relevantnim zakonima. ${ }^{129}$

U nastavku ovoga dijela razmotrit će se kaznene materijalne odredbe posebnoga dijela KZ-a, kojima su uređeni tzv. klasični oblici aktivnog i pasivnog podmićivanja.

\subsubsection{Regulacija djela primanje mita i davanje mita prema $\mathrm{KZ}-\mathrm{u}$}

U tipične koruptivne pojave podmićivanja, koja su sadržana u glavi dvadesetosmoj KZ-a (Kaznena djela protiv službene dužnosti) i svojstvena javnom sektoru, prema recentnoj kaznenoj praksi u predmetima povezanima s namještanjem rezultata sportskih natjecanja, spadaju: a) primanje mita iz članka 293. KZ-a i b) davanje mita iz članka 294. KZ-a.

\subsubsection{Primanje mita}

Primanje mita iz članka 293. KZ-a klasičan je oblik podmićivanja i kazneno je djelo protiv službene dužnosti. ${ }^{130}$ To kazneno djelo ima tri pojavna oblika: a) pravo pasivno podmićivanje, uređeno stavkom 1., nepravo pasivno podmićivanje, uređeno

126 Usp. Čizmić, J., Kačer B., „Pravni izvori sportskog (materijalnog i postupovnog) prava“, u Kačer, H. (ur.), Sportsko pravo (udžbenik), Pravni fakultet Sveučilišta u Splitu, Split, 2018., str. 15.

127 Ibid., str. 35.

128 Ibidem.

129 Ibidem.

130 Dragičević Prtenjača (2014.), op. cit. (bilj. 69.), str. 262. 
stavkom 2. i naknadno pasivno podmićivanje uređeno u stavku $3 .{ }^{131}$ Unatoč ovakvoj formi, nepravo pasivno podmićivanje koje je regulirano stavkom 2., u stvari je temeljni oblik djela. ${ }^{132}$

Počinitelj nepravog pasivnog podmićivanja jest službena ili odgovorna osoba koja zahtijeva ili primi mito, ili koja prihvati ponudu ili obećanje mita za sebe ili za drugoga da unutar ili izvan granica svoje ovlasti obavi službenu ili drugu radnju koja bi se morala obaviti, ili da ne obavi službenu ili drugu radnju koja se ne bi smjela obaviti, a može se kazniti kaznom zatvora od jedne do osam godina. ${ }^{133}$

Pravo pasivno podmićivanje čini ,službena ili odgovorna osoba koja zahtijeva ili primi mito, ili koja prihvati ponudu ili obećanje mita za sebe ili drugoga da unutar ili izvan granica svoje ovlasti obavi službenu ili drugu radnju koja se ne bi smjela obaviti, ili da ne obavi službenu ili drugu radnju koja bi se morala obaviti. ${ }^{134} \mathrm{Za}$ pravo pasivno podmićivanje, u odnosu na ostale oblike razmatranog djela propisana je najstroža kazna u trajanju od jedne do deset godina zatvora, upravo iz razloga što počinitelj ide za tim da krši ili ne obavi svoju dužnost koju bi morao i riječ je o kvalificiranom obliku nepravog pasivnog podmićivanja. ${ }^{135}$

Kod pravog pasivnog podmićivanja primatelj mita obvezuje se na kršenje ili neobavljanje svoje dužnosti, dok kod nepravog pasivnog podmićivanja počinitelj privatizira službu, pa se primanjem, odnosno zahtijevanjem mita ne obvezuje na kršenje ili neobavljanje službe već, upravo suprotno, na obavljanje sukladno propisima ili neobavljanje onoga što ionako ne bi smio učiniti. ${ }^{136}$ Za primanje mita je inače karakteristično da ga mogu počiniti samo službene ili odgovorne osobe koje su definirane u članku 87. stavcima 3., 5. i 6. KZ-a i stoga je to kazneno djelo delictum proprium. ${ }^{137}$

\subsubsection{Davanje mita ${ }^{138}$}

Iz zakonskog opisa kaznenog djela davanja mita, koje je sadržano u članku 294. KZ-a, jasno proizlazi da je ono dovršeno već predajom ili obećanjem dara ili kakve druge koristi službenoj ili odgovornoj osobi kako bi ona obavila ili propustila obaviti neku službenu ili drugu radnju (o tomu je li smjela ili morala obaviti tu radnju razlikuju se stavci 1. i 2. toga članka), bez obzira na to je li službena ili odgovorna osoba i prihvatila takav dar ili obećanje dara ili koristi, jer o odgovoru

131 Ibid., str. 263.

132 Ibidem.

133 Ibidem.

134 Ibidem.

135 Ibid., str. 264.

136 Ibidem.

137 Ibidem.

138 Cijeli odjeljak 2.3.1.2. s neznatnim izmjenama čini navođenje dijela doktorske disertacije autora Galiot (2018.), op. cit. (bilj. 24), str. 237 do 239 i 241. 
na to pitanje ovisi samo postojanje njene odgovornosti za neki od oblika kaznenog djela iz članka 293. KZ-a, a ne i kaznena odgovornost davatelja mita. ${ }^{139}$

$\mathrm{KZ}$, bez obzira na to je li smjela ili morala obaviti ili propustiti obaviti neku službenu ili drugu radnju, poznaje dva temeljna oblika „klasičnog“ davanja mita: a) tzv. pravo aktivno podmićivanje i b) tzv. nepravo aktivno podmićivanje. S tim u vezi nije pravno odlučno je li mito namijenjeno primatelju, prema kojem su izravno usmjerene radnje počinjenja, ili se radi o nekoj drugoj osobi. Za „drugu osobu“ ne traži se neko posebno svojstvo ili da je u kakvom posebnom odnosu s primateljem. Bitno je da je mito namijenjeno tog drugoj osobi za koju davatelj mita zna, odnosno za koju, u pravilu, znaju obje zainteresirane strane u korupcijskoj razmjeni (savezu). Za raščlambu je li riječ o pravom ili nepravom aktivnom podmićivanju ključno je da sud u svakom konkretnom predmetu, primjenom pravila o teretu dokazivanja, utvrdi pravi sadržaj (korupcijskog) sporazuma o podmićivanju (mitu), pod uvjetom da je prethodno sklopljen odnosno za što se mito dalo, (po)nudilo ili obećalo. Bačić smatra da ako se ne bi dalo točno razgraničiti je li riječ o pravom ili nepravom podmićivanju, tada bi to kazneno djelo valjalo kvalificirati kao obično podmićivanje - nepravo podmićivanje, jer je to zapravo osnovno djelo. ${ }^{140}$

Svatko tko službenoj ili odgovornoj osobi ponudi, dade ili obeća mito namijenjeno toj ili drugoj osobi da unutar ili izvan granica svoje ovlasti obavi službenu ili drugu radnju koju ne bi smjela obaviti ili da ne obavi službenu ili drugu radnju koju bi morala obaviti, kaznit će se kaznom zatvora od jedne do osam godina (čl. 294. st. 1. KZ-a). Tada govorimo o postojanju djela pravog aktivnog podmićivanja. S druge strane, ako tko službenoj ili odgovornoj osobi ponudi, dade ili obeća mito namijenjeno toj ili drugoj osobi da unutar ili izvan granica svoje ovlasti obavi službenu ili drugu radnju koju bi morala obaviti ili da ne obavi službenu ili drugu radnju koju ne bi smjela obaviti, kaznit će se kaznom zatvora od šest mjeseci do pet godina (čl. 294. st. 2. KZ-a). U toj situaciji riječ je o nepravom aktivnom podmićivanju. „Nepravo“ se ostvaruje zakonitošću same službene ili druge radnje, radi koje se daje mito. Vrhovni sud je zaključio: ... Takvo je njegovo postupanje protupravno i predstavlja kazneno djelo davanja mita iz čl. 294. st. 2. KZ/l1 bez obzira što je službena osoba postupala u okviru pravila službe te je obavila radnju carinjenja koju bi na isti način ionako obavila. Naime, radi se o nešto blažem vidu korupcije, o tzv. nepravom podmićivanju kojim se također, kao i kod pravog podmićivanja, podriva normalno funkcioniranje državnih službi, jer se službenim osobama daje nešto što im ne pripada. Davatelj mita se želi osigurati da očekivana radnja bude obavljena ili želi da se ona ubrza, no i na taj način čini kazneno djelo, bez obzira što time službena osoba nije postupala formalno nepravilno... ${ }^{141}$ Dakle, prema ustaljenoj sudskoj praksi, za postojanje nepravog aktivnog podmićivanja

139 Iz presude Županijskog suda u Zagrebu broj Kov-Us-43/14 od 18. lipnja 2014. (predana autorima neposredno od pisarnice toga suda).

140 Bačić, F., „Korupcija i antikorupcijsko kazneno pravo“, Hrvatski ljetopis za kazneno pravo $i$ praksu, 2000., str. 834.

${ }^{141}$ Tako u presudi poslovni broj I Kž-Us-35/16-6 od 1. lipnja 2016.; dostupna na: https://sudskapraksa. csp.vsrh.hr/ (10. IV. 2017.). 
nije bitno je li službena ili odgovorna osoba postupala sukladno propisima i je li pritom za državu, državni proračun nastala kakva šteta. Pravno je bitno je li za takvu zakonitu radnju ili propuštanje postupanja (koju ionako ne bi smjela ili koju bi morala obaviti) dano, obećano ili ponuđeno mito službenoj ili odgovornoj osobi. U odnosu na pravo aktivno podmićivanje ovaj vid podmićivanja jest blaži oblik djela davanja mita, pa ga stoga zakonodavac i blaže kažnjava.

Izraz „službena radnja“ predstavlja autoritativan, legalan i legitiman čin na koji je nositelj javne ovlasti ovlašten i obvezan, a što pripada njegovu djelokrugu poslova i njegovoj nadležnosti. Ona bi, kao takva, pripadala ponajprije pripadnicima tijela državne uprave i drugim državnim tijelima, tijela jedinica lokalne i područne (regionalne) samouprave i pravnih osoba kojima je povjerena javna ovlast, ali i drugim nositeljima javne ovlasti. Pod „drugom radnjom“ smatramo da se može razumjeti svaka radnja na koju je nositelj javne ovlasti ovlašten i obvezan, a koja ne predstavlja službenu radnju. Dakle, koja ne obuhvaća autoritativno djelovanje. Smatramo da je riječ o jednostavnijim, tehničkim i administrativnim poslovima odnosno upravnim radnjama koje nisu dio funkcije ili položaja već određenog radnog mjesta ili je riječ o radnjama koje su ,prateće“ službenima.

\section{SPORNI ASPEKTI KAZNENOPRAVNE ODGOVORNOSTI ZA NAMJEŠTANJE REZULTATA SPORTSKIH NATJECANJA U SUDSKOJ PRAKSI}

U ovom dijelu rada iznosi se pregled recentne tzv. uskočke sudske prakse u materiji kaznene odgovornosti za namještanje rezultata sportskih natjecanja. Pod tzv. uskočkom praksom, podrazumijevaju se presude Vrhovnog suda Republike Hrvatske i županijskih sudova u Zagrebu, Splitu, Rijeci i Osijeku. ${ }^{142}$ Pregled prakse daje se po pojedinim spornim pitanjima.

\subsection{Podvođenje sudionika sportskog natjecanja pod pojam odgovorne osobe}

U sudskoj praksi pokazalo se dvojbenim podvođenje pojedinih sudionika sportskog natjecanja pod pojam odgovorne osobe, kako je on definiran u članku 87. stavku 6. KZ-a. To se odnosilo na: a) (glavnog nogometnog) suca, b) igrača, c) trenera i d) člana Komisije nogometnih sudaca Izvršnog odbora sportskog saveza. U svim tim situacijama, usprkos osporavanju optuženika za davanje i primanje mita, sudovi su zaključili da je riječ o odgovornim osobama i da su kazneno odgovorni za podmićivanje zbog namještanja rezultata sportskih natjecanja.

142 Analizirane odluke pribavljene su putem https://sudskapraksa.csp.vsrh.hr i dijelom dostavljene autorima elektroničkom poštom od pisarnica županijskih sudova u svibnju 2020. 
Kada je riječ o (glavnom nogometnom) sucu, Vrhovni sud Republike Hrvatske ${ }^{143}$ je, u presudi poslovni broj I Kž-7/2016-7 od 11. rujna 2019. ${ }^{144}$ vezano za istaknuti prijepor, zaključio da je na utakmicama na kojima je sudio kao glavni nogometni sudac imao svojstvo odgovorne osobe i da se službena radnja koju nije smio obaviti odnosi na pristrano suđenje u korist određenog nogometnog kluba. Sud je obrazložio to time da je odgovorna osoba fizička osoba kojoj je povjereno obavljanje poslova iz područja djelovanja pravne osobe, pa da se stoga optuženi može podvesti pod odgovornu osobu, budući da je, kao glavni nogometni sudac, na utakmicama obavljao poslove iz područja djelovanja pravne osobe - Hrvatskog nogometnog saveza. ${ }^{145},{ }^{146}$ Takvo pravno shvaćanje prešutno bi proizlazilo vezano za status odgovorne osobe nogometnog suca i iz presude Vrhovnog suda poslovni broj I Kž662/2006-5 od 23. listopada 2007. ${ }^{147}$ Sud je tada, potvrđujući osuđujuću presudu ${ }^{148}$ za primatelja mita i pomagača u davanju mita, zaključio: ... pravilno je sud prvog stupnja utvrdio, da je ovaj od opt. S. S., predsjednika NK „H. D. “ zatražio 10.000 EUR-a da pošteno, dakle, poštujući pravila nogometne igre, sudi utakmicu između $N K$ „S. B. “ i NK „H. D. “, da je ovaj (S. S. na to pristao, a opt. J. S. - pomagač u davanju mita da je ovom (opt. I. K. - inače primatelj mita) predao zatraženi iznos od 10.000 EUR-a, koji je prije toga dobio od S. S... U konkretnom predmetu optuženik je osuđen za počinjenje nepravog oblika pasivnog podmićivanja, budući da je (za) tražena od primatelja mita kao odgovorne osobe da je učinio zakonitu radnju (koju bi svakako mora obaviti).

143 Ili skraćeno: Vrhovni sud.

144 Presuda broj I Kž-82/2012-8 od 18. prosinca 2013. dostupna na: https://sudskapraksa.csp.vsrh. hr/ (18. V. 2020.). Njome je potvrđena presuda Županijskog suda u Osijeku broj K-Us-10/2015-6 od 14. listopada 2015. (dostavljena je autorima elektroničkom poštom od sudske pisarnice toga suda).

145 Iz sadržaja presude broj Kž-7/2016-7: ... Nadalje, prvostupanjski je sud u 5. odlomku 15. stranice pobijane presude, dostatnim razlozima obrazložio da je na utakmicama na kojima je sudio kao glavni nogometni sudac optuženi T. R. imao svojstvo odgovorne osobe, a ujedno i jasnim razlozima obrazložio $i$ u čemu se sastoji dar koji mu je ponuđeni, koji je optuženi R. i prihvatio i kao da se službena radnja koju nije smio obaviti odnosi na pristrano suđenje u korist nogometnog kluba „V. M. “. Stoga, nema govora da bi, zbog nedostatka razloga, ovim o odlučnim činjenicama, bila ostvarena bitna povreda kaznenog postupka iz članka 468. stavka 1. točke 11. ZKP/08; zbog čega je i promašeno ukazivanje na stajališta Ustavnog suda Republike Hrvatske izražena u odluci od 24. srpnja 2015. broj U-III-4149/2014... Naime, u smislu odredbe članka 97. stavka 6. KZ/11; odgovorna osoba je fizička osoba kojoj je povjereno obavljanje poslova iz područja djelovanja pravne osobe, pa s obzirom na to da je optuženi T. R. kao glavni nogometni sudac na utakmicama 23. i 25. kola Prve županijske nogometne lige (...) obavljao poslove iz područja djelovanja pravne osobe - Hrvatskog nogometnog saveza, to nema dvojbe da je imao svojstvo odgovorne osobe...

146 Iz presude broj K-Us-10/2015-6 proizlazi: .. U izvršenju predmetnog kaznenog djela 3. optuženi $T$. $R$. postupa s izravnom namjerom, budući je s obzirom na radnje koje je poduzimao u inkriminiranom razdoblju očigledno pokazao da je svjestan svoga djela $i$ da je htio njegovo izvršenje. Kao glavni nogometni sudac na predmetnim nogometnim utakmicama 3. optuženi je bio odgovorna osoba i bio je dužan unutar granica svojih ovlasti glavnog nogometnog suca obavljati radnje koje se moraju obaviti, suditi u skladu s pravilima nogometne igre. Međutim on po traženju M. N. tako ne postupa nego prihvaća da unutar granica svojih ovlasti obavi radnje koje ne bi smio obaviti. Pritom je svjestan svojih ovlasti nogometnog suca. Unatoč tome on prihvaća ponudu i obećanje mita M. N. te od istoga i prima mito kako bi obavio radnje koje ne bio smio obaviti čime jasno i nedvojbeno manifestira svoje htijenje za počinjenje kaznenog djela..

147 Tekst presude dostupan na: https://sudskapraksa.csp.vsrh.hr/ (18. V. 2020.).

148 Županijskog suda u Zagrebu poslovni broj K-Us-4/2005 od 23. listopada 2007. 
Doc. dr. sc. Mijo Galiot i Silvio Čović, dipl. iur.: Odgovornost za namještanje rezultata sportskih natjecanja... Zbornik radova Pravnog fakulteta u Splitu, god. 58, 1/2021, str. 315-348

Pri razmatranju statusa odgovorne osobe igrača (amatera) i trenera (nogometnih klubova) Vrhovni sud je, u presudi poslovni broj I Kž-Us-82/2012-8 od 18. prosinca 2013., ${ }^{149}$ potvrđujući presudu Županijskog suda u Zagrebu broj K-Us-9/2011 od 13. prosinca 2011., ${ }^{150}$ smatrajući da je riječ o odgovornim osobama, zauzeo sljedeća pravna shvaćanja. Sud je istaknuo da su nogometaši (pa i amateri) odgovorne osobe, jer nastupajući za svoj klub, igrajući nogomet na nogometnim utakmicama obavljaju djelatnost koja im je na temelju ugovora s klubom povjerena, a koja je djelatnost iz područja djelovanja kluba kao pravne osobe. Tada je optuženik, igrač osporio da bi imao svojstvo odgovorne osobe u smislu članka 89. točke 7. KZ/97.a, budući da nije bio profesionalni igrač. ${ }^{151}$ Okrivljenik, igrač je smatrao da se ne može smatrati odgovornom osobom jer njemu nije povjeren djelokrug poslova u nogometnom klubu, budući da je on registriran kao obrtnik, odnosno prema članku 22. ZoS-a, fizička osoba koja samostalno obavlja sportsku djelatnost. Jedna od zadaća, odnosno jedan djelokrug poslova, koji je i temeljna djelatnost nogometnog kluba, jest i održavanje utakmica, pri čemu utakmice igraju igrači, koji time izvršavaju poslove iz djelokruga pravne osobe, odnosno nogometnog kluba kojem pripadaju. ${ }^{152}$

$\mathrm{U}$ istom predmetu sud je istaknuo i da su treneri nogometnih klubova, organizirajući $i$ vodeći treninge pripremaju igrače za nogometne utakmice, a određujući uoč i i na nogometnim utakmicama koji će igrači igrati i na kojoj poziciji, obavljaju poslove iz djelokruga poslova iz područja djelovanja nogometnog kluba kao pravne osobe. ${ }^{153}$

149 Tekst presude dostupan na: https://sudskapraksa.csp.vsrh.hr/ (18. V. 2020.).

150 Iz presude I Kž-Us-82/2012-8 proizlazi da su prvostupanjskom presudom optuženici ... proglašeni krivim da su u inkriminiranom periodu organizirali više igrača, trenera $i$ sportskih djelatnika Prve hrvatske nogometne lige, kojima su predavali novac ili obećali predaju novca radi namještanja rezultata i tijeka nogometnih utakmica, da bi nakon postignutih dogovora u raznim kladionicama uplaćivali znatne iznose novca, koje su uplate službenici kladionice zaprimali ne znajući za ove dogovore te im isplaćivali dobitke...

151 Prema čl. 6. st. 2. ZoS-a, osoba koja sudjeluje u sportskim natjecanjima kao član pravne osobe koja obavlja sportsku djelatnost sudjelovanja u sportskim natjecanjima može imati status profesionalnog sportaša ili amatera. Nešto slobodnijim tumačenjem (koje je to primjerenije jer nikoga i ničija prava ne ugrožava), in favorem sporta i sportaša, sigurno je da bi i onaj tko obavlja samostalnu sportsku djelatnost sudjelovanja u sportskim natjecanjima trebao moći dobiti status bilo amatera bilo profesionalca - tako Kačer, H., Kačer B. (2018.), op. cit. (bilj. 46), str. 41.

152 Dragičević Prtenjača (2014.), op. cit. (bilj. 69.), str. 266.

153 Iz presude broj I Kž-Us-82/2012-8: ... Nije sporno da je opt. B. bio registriran kao igrač amater u N. C. S. koji je pravna osoba, a nogometaši su odgovorne osobe kako to osnovano zaključuje prvostupanjski sud, jer nastupajući za svoj klub, igrajući nogomet na nogometnim utakmicama obavljaju djelatnost koja im je na temelju ugovora s klubom povjerena, a koja je djelatnost iz područja djelovanja kluba kao pravne osobe. U odnosu na opt. J. koji također osporava to svojstvo utvrđeno je da je u HNS registriran kao voditelj Omladinske škole, a imao je ugovor o profesionalnom treniranju u N. C. S. pa prvostupanjski sud osnovano zaključuje da je imao svojstvo odgovorne osobe u smislu čl. 89. st. 7. KZ/97, jer treneri organizirajući $i$ vodeći treninge pripremaju igrače za nogometne utakmice, a određujući uoči i na nogometnim utakmicama koji će igrači igrati i na kojoj poziciji, obavljaju poslove iz djelokruga poslova iz područja djelovanja nogometnog kluba kao pravne osobe... 
Vezano za status odgovorne osobe predsjednika izvršnoga tijela sportskog saveza, ${ }^{154}$ Vrhovni sud je, u presudi poslovni broj I Kž-Us-6/2015-8 od 17. svibnja 2017. ${ }^{155}$ između ostaloga, istaknuo bez obzira na formalističko tumačenje Izvršnog odbora Hrvatskog nogometnog saveza (skraćeno: IO HNS) pojedinih odredbi Pravilnika o radu Izvršnog odbora i njegovih organa i Pravila o uvjetima, načinu i postupku određivanja nogometnih sudaca, kontrolora i delegata kontrolora za utakmicu Prve, Druge i Treće lige i Završnice Hrvatskog nogometnog kupa, praćenju i analize suđenja i Propozicija natjecanja MaxTv Prve HNL-a, s pravom je sud prvoga stupnja, ${ }^{156}$ koji je jedini u kaznenom postupku ovlašten tumačiti $i$ primjenjivati propise koji se odnose na predmetna kaznena djela ${ }^{157}$ utvrdio da je optuženik, predsjednik Komisije IO HNS-a faktički imao ovlasti kroz rad u Komisiji određivati koji će suci suditi u pojedinim utakmicama. Sud prvoga stupnja s pravom ukazuje da takve ovlasti optuženika proizlaze iz okolnosti da Komisija, čiji je on predsjednik, predlaže IO HNS-a, u kojem je on istovremeno dopredsjednik, na usvajanje prijedloga liste sudaca i kontrolora, brine se o određivanju nogometnih sudaca, predlaže IO imenovanje Povjerenika za suđenje. Sud je u tom kontekstu zaključio iako je Povjerenik za suđenje formalno nadležan određivati suce za suđenje u pojedinim utakmicama, kroz stvarni utjecaj koji je optuženik imao u Komisiji i IO HNS-a u odnosu na usvajanje liste sudaca i imenovanje povjerenika, kroz. praćenje kvalitete rada sudaca $i$ kroz utjecaj na njihovo ocjenjivanje i napredovanje te kroz njegov utjecaj na rad imenovanih Povjerenika, u kojem pravcu je pravilno prihvaćen uvjerljiv iskaz svjedoka, pa je stoga sud pravilno zaključio da je optuženik bio u poziciji da određuje koji od sudaca će suditi na pojedinim utakmicama i to je u stvarnosti $i$ činio. U tom dijelu je sud završno istaknuo da je u konkretnim okolnostima optuženik pravilno podveden pod odgovornu osobu, budući da je s obzirom na svoje funkcije i utjecaje, mogao određivati koji će nogometni suci suditi na pojedinim utakmicama, te da je optuženik primitak dara zahtijevao i primio za

154 U konkretnom predmetu bila je riječ o predsjedniku Komisije nogometnih sudaca Izvršnog odbora Hrvatskog nogometnog saveza (skraćeno: HNL).

155 Tekst presude dostupan na: https://sudskapraksa.csp.vsrh.hr/ (18. V. 2020.).

156 Županijski sud u Zagrebu u presudi poslovni broj K-Us-50/2012 od 25. ožujka 2014. (predana autorima neposredno 2016. od pisarnice toga suda).

157 U konkretnom predmetu riječ je o kaznenim djelima primanje mita i davanje mita. 
Doc. dr. sc. Mijo Galiot i Silvio Čović, dipl. iur.: Odgovornost za namještanje rezultata sportskih natjecanja... Zbornik radova Pravnog fakulteta u Splitu, god. 58, 1/2021, str. 315-348

radnje koje su bile u granicama njegovih faktičnih ovlasti. ${ }^{158}$ Može se zaključiti da su iznesena pravna stajališta u skladu is doktrinarnim promišljanjem Derenčinovića. ${ }^{159}$ Naime, odgovorna osoba ne mora (nužno) uvijek biti osoba koja je, kao odgovorna, određena zakonom, aktom o osnivanju ili odlukom tijela upravljanja pravne osobe i česta je praksa da se formalnim određivanjem odgovorne osobe zapravo ciljano prikriva stvarna odgovorna osoba. To znači da se u svakom pojedinom kaznenom predmetu, slobodnom ocjenom izvedenih dokaza i analizom rezultata dokaznog postupka, valja utvrditi je li optuženik uistinu i faktično, s obzirom na svoj utjecaj i položaj unutar pravne osobe, mogao obaviti traženu službenu radnju za koju je

158 Iz presude broj K-Us-50/2012: ... Prema članku 3. Statuta Hrvatskog nogometnog saveza (donesen na sjednici Skupštine HNS 2. lipnja 2008.) Savez je neprofitabilna osoba, i upisuje se u Registar udruga koji vodi državno tijelo nadležno za opću upravu i Registar športskih djelatnosti koji vodi ured državne uprave u Gradu Zagrebu. Sukladno članku 2. Zakona o udrugama (NN 88/01, 11,02) danom upisa u registar udruga HNS je stekao svojstvo pravne osobe, a prema članku 74. Statuta HNS-a Savez. ostvaruje prihode vlastitom djelatnošću, iz sredstava koje Republika Hrvatska osigurava u Državnom proračunu, uplatom članarina i pristojbi, sponzorskih ugovora, novčanih kazni koje su izrekla nadležna tijela Saveza, dobrovoljnih priloga $i$ darova $i$ drugih izvora sukladno zakonu, dakle, HNS stvara $i$ pribavlja sredstva i njima raspolaže pa prema tome ima status pravne osobe u smislu članka 89. stavak 6. KZ/97. Pravilnikom Hrvatskog nogometnog saveza o radu Izvršnog odbora te njegovih organa uređen je rad i organizacija Izvršnog odbora HNS-a, sastav, djelokrug rada, nadležnost i broj članova komisija pa tako i Komisije nogometnih sudaca, između ostalog, predlaže Izvršnom odboru Saveza na usvajanje prijedlog liste sudaca i kontrolora suđenja za sve stupnjeve natjecanja koji su u nadležnosti Saveza, osim za Treću $i$ Četvrtu HNL, brine o određivanju nogometnih sudaca za sve stupnjeve natjecanja koji su $u$ nadležnosti Saveza sukladno propisima Saveza, predlaže povjerenika za suđenje Prve, Druge, Treće $i$ Četvrte HNL, završnice HNK, međunarodne utakmice Prve i Druge HNML i Prve i Druge HNLŽ. Prema članku 1. Pravila o uvjetima, načinu i postupku određivanja nogometnih sudaca, kontrolora $i$ delegata kontrolora za utakmice prve, druge, treće, četvrte HNL-a i završnice HNK-a, praćenju $i$ analizi suđenja Povjerenik za određivanje nogometnih sudaca za određeni stupanj natjecanja određuje nogometne suce, pomoćne suce $i$ četvrtog nogometnog suca s prethodno utvrđenih $i$ verificiranih lista za suce za pojedine stupnjeve natjecanja, međutim, članovi Komisije nogometnih sudaca pa tako i njezin Predsjednik koji je ujedno $i$ dopredsjednik Izvršnog odbora HNS, dužni su nadzirati rad Povjerenika $i$ nogometnih sudaca $i$ osiguravati da se pri određivanju nogometnih sudaca i druge propise kojima je regulirana nogometna igra i ponašanje nogometnih djelatnika kao što su Statut svjetske nogometne organizacije - FIFA-e. Disciplinski kodeks i Etički kodeks FIFA-e, Kodeks o ponašanju nogometnih djelatnika HNS-a i Disciplinski pravilnik HNS, a kako bi, u konačnici, rezultat nogometne utakmice bio pokazatelj spremnosti, znanja i sportske sreće suprostavljenih klubova. Kao predsjednik Komisije za nogometne suce I. optuženi Ž. Š. je imao ovlasti kroz rad u Komisiji određivati suce za pojedine nogometne utakmice, što je stvarno i činio, a kako je to obrazloženo, a kroz praćenje kvalitete njihova rada imao je utjecaj na njihovo ocjenjivanje i napredovanje, što su sve aktivnosti koje podrazumijeva djelatnosti „briga o sucima“ iz. članka 24. citiranog Pravilnika I. optuženom Ž. Š. je, dakle, bio povjeren određen djelokrug poslova iz. područja djelovanja pravne osobe pa je imao svojstvo odgovorne osobe u smislu članka 89. stavak 7. KZ/97. Sud nije prihvatio Tumačenje Izvršnog odbora HNS članka 24. stavak 1. alineja 2. Pravilnika o radu Izvršnog odbora $i$ njegovih organa te tumačenje o načinu određivanja sudaca na utakmicama $i$ tko je odgovorna osoba za njihovo određivanje iz razloga što je pojam počinitelja kaznenog djela iz. članka 347. stavak 1., odnosno odgovorne osobe određen člankom 89. stavak 7. KZ/97, tumačenje kojih članaka Kaznenog zakona nije u nadležnosti Izvršnog odbora HNS. Imajući u vidu ovlasti I. optuženika koje proizlaze iz citiranih propisa HNS-a, kao i njegovo djelovanje u HNS-u sud je zaključio, a kako je to i obrazloženo, da ima status odgovorne osobe...

159 V. infra 2.1.3. 
Doc. dr. sc. Mijo Galiot i Silvio Čović, dipl. iur.: Odgovornost za namještanje rezultata sportskih natjecanja... Zbornik radova Pravnog fakulteta u Splitu, god. 58, 1/2021, str. 315-348

zahtijevao ili primio mito ili za koju je prihvatio ponudu ili obećanje mita za sebe ili drugoga. ${ }^{160}$

\subsection{O službenoj radnji sudionika sportskog natjecanja s aspekta odgovornosti za podmićivanje}

Pod (ciljnom) službenom radnjom sudionika sportskog natjecanja (odgovorne osobe), koju poduzima unutar granica svoje ovlasti, a koju ne bi smjela obaviti (uz primanje mita) podrazumijevalo se: a) osiguranje određenom nogometnom klubu „korektnog“ suđenja u prvenstvu i sastavljanje liste „poželjnih“ sudaca od strane predsjednika Komisije nogometnih sudaca Izvršnog odbora Hrvatskog nogometnog saveza (koja, na temelju članka 24. stavka 1. alineje 2. Pravilnika o radu Izvršnog odbora Hrvatskog nogometnog saveza, brine o određivanju nogometnih sudaca za sve stupnjeve natjecanja koji su u nadležnosti Saveza sukladno njegovim propisima), ${ }^{161}$ b) osiguranje „poštenog “ suđenja određenom nogometnom klubu $i$ „,delegiranje“ nogometnih sudaca na pojedinim prvenstvenim utakmicama po odabiru tog nogometnog kluba - postupanje suprotno članku 4. Pravila Hrvatskog nogometnog saveza o uvjetima, načinu i postupku određivanja nogometnih sudaca, kontrolora i delegata - kontrolora za utakmice prve, druge, trećih i četvrtih HNL-a $i$ završnice HNK, praćenju i analizi suđenja, što je zatraženo od optuženika, člana Komisije nogometnih sudaca Izvršnog odbora Hrvatskog nogometnog saveza koji

$160 \mathrm{U}$ tom dijelu valja skrenuti pozornost na jedno bitno pravno stajalište Visokog upravnog suda Republike Hrvatske, koje je taj sud izrazio u odluci poslovni broj Usoz-97/2014-4 od 27. veljače 2015. Sud se u konkretnom predmetu, po zahtjevu nogometnog kluba za ocjenu zakonitosti odluke Komisije za žalbe HNS-a, oglasio stvarno nenadležnim i predmet ustupio Upravnom sudu u Splitu na nadležno postupanje, budući da je smatrao da je riječ o tužbi u smislu odredbe članka 12. stavka 2. točke 1. Zakona o upravnim sporovima (NN, br. 20/10, 143/12, 152/14, 94/16 i 29/17, u daljnjem tekstu: ZUS). Osporenom odlukom potvrđena je odluka prvostupanjskog tijela, disciplinskog suca HNS-a za prvu nogometnu ligu, kojom je podnositelju izrečena kazna igranja dvije (2) prvenstvene ili kup utakmice na igralištu na kojem klub nastupa kao domaćin seniorske momčadi, bez prisutnosti gledatelja. Sud je smatrao da je riječ o pojedinačnoj odluci, tretirajući Komisiju za žalbe HNS-a javnopravnim tijelom u smislu odredbe članka 1. Zakona o općem upravnom postupku (NN, br. 47/09, u daljnjem tekstu: ZUP). Prema čl. 2 . st. 1. ZUS-a, cilj toga zakona jest osigurati zakonitost i sudsku zaštitu prava i pravnih interesa fizičkih i pravnih osoba i drugih stranaka povrijeđenih pojedinačnom odlukom ili postupanjem javnopravnog tijela, dok je prema čl. 3. st. 1. toč. 1. ZUS-a predmet upravnog spora ocjena zakonitosti pojedinačne odluke kojom je javnopravno tijelo odlučilo o pravu, obvezi ili pravnom interesu stranke u upravnoj stvari (upravni akt) protiv koje nije dopušteno izjaviti redovni pravni lijek. Elementi pojma pojedinačne odluke pretpostavljaju određenog nosioca, autoritativnost, pravno djelovanje, konkretnost i da se takva odluka donosi u nekoj upravnoj stvari. U čl. 1. ZUP-a normirane se četiri skupine javnopravnih tijela: a) tijela državne uprave, b) druga državna tijela, c) tijela jedinice lokalne i područne (regionalne) samouprave te d) pravne osobe koje imaju javne ovlasti. Sukladno čl. 2. st. 1. ZUP-a upravnom stvari smatra se svaka stvar u kojoj javnopravno tijelo u upravnom postupku rješava o pravima, obvezama ili pravnim interesima fizičke ili pravne osobe ili drugih stranaka neposredno primjenjujući zakone, druge propise i opće akte kojima se uređuje odgovarajuće upravno područje. Iz navedenih zakonskih normi može se zaključiti da kumulativne pretpostavke da bi se pojedini predmet smatrao upravnom stvari podrazumijevaju: 1. odlučivanje od strane javnopravnog tijela, 2. odlučivanje u upravnom postupku, 3. odlučivanje o pravima, obvezama ili pravnim interesima fizičkih ili pravnih osoba ili drugih stranaka i 4. neposredna primjena zakona, drugih propisa ili općih akata, kojima je uređeno pojedino upravno područje.

161 Tako Županijski sud Zagreb u presudi broj K-Us-50/2012 od 25. ožujka 2014., predana autorima neposredno 2016. 
je ujedno i član Komisije za određivanje sudaca za suđenje Prve i Druge HNL i završnice HNL, ${ }^{162}$ c) pristrano suđenje u korist određenog nogometnog kluba (koje je suprotno pravilima nogometne igre), što je zatraženo od (glavnog nogometnog) suca $^{163}$ i d) sudjelovanje (igrača) u sportskom natjecanju, odnosno igranje utakmice $s$ ciljem namještanja (manipulacije) rezultata natjecanja. ${ }^{164}$

Vezano za konstitutivna obilježja kaznenog djela primanja mita, osobito je bitno istaknuti da je sud u tri situacije izrazio pravno stajalište da za opstojnost toga djela nije pravno relevantno je li podmićena (i zatražena) radnja uopće poduzeta. U prvoj situaciji Vrhovni je sud zaključio sljedeće: je li podmićeni sudac uistinu na konkretnim utakmicama pristrano sudio nije obilježje djela primanja mita i nije pravno relevantna činjenica. ${ }^{165} \mathrm{U}$ drugom predmetu, koji se vodio radi počinjenja djela (aktivnog i pasivnog) podmićivanja isti je sud istaknuo da je za postojanje djela primanja mita dostatno da je igrač prihvatio ponudu (mito) bez obzira na to je li on uistinu igrao i je li imao uopće mogućnost sudjelovati u namještanju rezultata utakmice. ${ }^{166} \mathrm{~S}$ tim u vezi valja skrenuti pozornost da je sud u istom predmetu zaključio: ... da svaki navod u činjeničnom opisu kaznenog djela ne predstavlja $i$ njegovo bitno obilježje, a u konkretnom slučaju navod da su optuženici postupali protivno Statutu Svjetske nogometne federacije FIFA-e i drugim aktima navedenim u činjeničnom opisu ne iziskuje i navođenje pojedinih odredbi s obzirom da je na temelju tih akata utvrđeno da su se nogometni djelatnici bili dužni pridržavati svih pravila i načela iz navedenih akata, što je i opširno obrazloženo u navedenoj presudi... I u trećem predmetu sud je zaključio da okolnosti jesu li „dogovoreni“ “ $i$ „poželjni“ suci uistinu sudili sa spiska koji je odredio određeni nogometni klub i jesu li ti suci u suđenju preferirali bilo koji klub, pa i onaj koji je sastavio spisak nisu relevantne za opstojnost kaznenog djela primanja mita, jer je to djelo ostvareno već u trenutku zahtijevanja mita za osiguranje određenom nogometnom klubu „korektnog“ suđenja u prvenstvu i sastavljanje liste „poželjnih“" sudaca od predsjednika Komisije nogometnih sudaca IO HNS-a ${ }^{167}$

\footnotetext{
162 V. bilj. 154 (K-Us-50/2012).

163 Tako Vrhovni sud u presudi broj I Kž-Us-7/2016-7 od 11. rujna 2019. i Županijski sud u Osijeku u presudi broj K-Us-10/2015-6 od 14. listopada 2015.

164 Tako u presudi Vrhovnog suda broj I Kž-Us-82/2012-8 i Županijskog suda u Zagrebu broj K-Us9/2011.

165 Vrhovni sud je, u presudi broj I Kž-Us-7/2016-7 od 11. rujna 2019., istaknuo: ... Međutim, s obzirom na to da se, prema zakonskom opisu kaznenog djela primanja mita iz članka 293. stavka 1. KZ/11., za ostvarenje bića tog kaznenog djela ne traži i poduzimanje radnje za čije obavljanje je primljeno mito ili prihvaćena ponuda ili obećanje mita, to ni u činjeničnom opisu tog kaznenog djela u izreci prvostupanjske presude, suprotno žalbenim tvrdnjama optuženog T. R., nije opisano „da je III-optuženik na tim utakmicama pristrano sudio“. Ta okolnost, dakle, nije obilježje predmetnog kaznenog djela pa, stoga, nije niti odlučna činjenica...

166 Iz presude broj I Kž-Us-82/2012-8 od 18. prosinca 2013.

167 Tako Vrhovni sud u presudi broj i Kž-Us-6/2015-8 (v. bilj. 156).
} 


\section{ZAKLJUČAK}

Sportska natjecanja postaju dramatičan izraz realnih kapitalističkih zbivanja i odnosa u kojima je, osim postizanja sportskih rezultata, glavni cilj maksimiziranje profita. Da bi se on ostvario, osobe u sustavu sporta, ali i subjekti povezani s klađenjem, nerijetko poduzimaju radnje s ciljem namještanja odnosno manipulacije rezultatima sportskih natjecanja. U europskoj pravnoj stečevini pojam manipulacije sportskim natjecanjima, koji je, mišljenja smo, gotovo istoznačnica s namještanjem u kaznenopravnom smislu, definiran je kao namjeran dogovor, čin ili propust s ciljem nepropisne izmjene rezultata ili tijeka sportskog natjecanja kako bi se djelomično ili u cijelosti dokinula nepredvidljiva priroda sportskog natjecanja s ciljem dobivanja neprimjerene prednosti za sebe ili za druge.

Zbog limitiranoga učinka stegovnih kazni i šire pojavnosti protupravnoga koruptivnog ponašanja u vidu podmićivanja u kontekstu tzv. manipulativnog odvijanja sportskih natjecanja pokazala se nužnom intervencija, osim sportskog, i kaznenog prava. Naime, riječ je ponajprije o koruptivnoj pojavi koja, iako je prisutna u sportu, prema istraženoj praksi kaznenih sudova, podliježe sankcioniranju prema normama kaznenog prava, kojima su uređeni tzv. klasični oblici aktivnog i pasivnog podmićivanja u javnom sektoru.

U sudskoj praksi, iako vrlo oskudnoj kada je riječ o kaznenoj odgovornosti osoba za počinjenje kaznenih djela davanja mita i primanja mita s ciljem namještanja rezultata sportskih natjecanja, pokazalo se spornim podvođenje sudionika tih natjecanja pod pojam odgovorne osobe kako je on definiran u članku 87. stavku 6. KZ-a. Analizom sadržaja pravomoćnih odluka pokazalo se i dvojbenim je li se pojedine koruptivne radnje poduzete s ciljem manipulacije rezultatima sportskih natjecanja mogu podvesti pod službenu radnju u kontekstu odgovornosti za počinjenje tzv. klasičnih oblika aktivnog i pasivnog podmićivanja te s obzirom na propisana konstitutivna obilježja tih kaznenih djela u tekstu (bićima) KZ-a.

Vezano za podvođenje pojedinih sudionika sportskog natjecanja pod pojam odgovorne osobe, sud je zaključio da se a) (glavni nogometni) sudac, b) igrač, c) trener i d) član izvršnoga tijela sportskog saveza mogu tretirati odgovornim osobama. Sud je smatrao da su nogometaši (pa i amateri) odgovorne osobe, jer nastupajući za svoj klub, igrajući nogomet na nogometnim utakmicama obavljaju djelatnost koja im je na temelju ugovora s klubom povjerena, a koja je djelatnost iz područja djelovanja kluba kao pravne osobe. Sudska je praksa pokazala da se to svojstvo u smislu kaznenopravne odgovornosti može priznati i (nogometnom) sucu, budući da je on na utakmicama obavljao poslove iz područja djelovanja pravne osobe - Hrvatskog nogometnog saveza. To se odnosi i na člana izvršnoga tijela sportskog saveza, ali i na trenere koji, organizirajući i vodeći treninge pripremaju igrače za nogometne utakmice, a određujući uoči i na nogometnim utakmicama koji će igrači igrati i na kojoj poziciji, obavljaju poslove iz djelokruga poslova iz područja djelovanja nogometnog kluba kao pravne osobe. 
Prema praksi sudova, službenom radnjom sudionika sportskog natjecanja s aspekta odgovornosti za podmićivanje podrazumijevalo se: a) osiguranje određenom nogometnom klubu „korektnog“ suđenja u prvenstvu i sastavljanje liste „poželjnih“" sudaca, b) osiguranje ,poštenog“" suđenja određenom nogometnom klubu i ,delegiranje“" nogometnih sudaca na pojedinim prvenstvenim utakmicama po odabiru tog nogometnog kluba, c) pristrano suđenje u korist određenog nogometnog kluba, što je zatraženo od suca i d) sudjelovanje igrača u sportskom natjecanju s ciljem namještanja (manipulacije) rezultata natjecanja. U tom kontekstu valja skrenuti pozornost i na nekoliko pravnih shvaćanja koja su bitna s aspekta ocjene opstojnosti kaznenih djela davanja mita i primanja mita povezanih s namještanjem rezultata sportskih natjecanja. Sud je zaključio: a) je li podmićeni sudac uistinu na konkretnim utakmicama pristrano sudio, nije obilježje djela primanja mita i nije pravno relevantna činjenica, b) za postojanje djela primanja mita dostatno je da je igrač prihvatio ponudu (mito) bez obzira na to je li on uistinu igrao i je li imao uopće mogućnost sudjelovati u namještanju rezultata utakmice i c) okolnosti jesu li poželjni suci uistinu sudili sa spiska koji je odredio određeni nogometni klub i jesu li ti suci u suđenju preferirali bilo koji klub, pa i onaj koji je sastavio spisak, nisu relevantne za opstojnost kaznenog djela primanja mita, jer je to djelo ostvareno već u trenutku zahtijevanja mita za osiguranje određenom nogometnom klubu „korektnog“ suđenja u prvenstvu i sastavljanje liste poželjnih sudaca.

Polazeći od rezultata analize zaštićenog pravnog dobra kod djela aktivnog i pasivnog podmićivanja u javnom sektoru i temeljnih pravnih pojmova povezanih s odgovornošću za podmićivanje s ciljem manipulacije rezultatima sportskih natjecanja, ali i od hrvatskog pozitivno pravnog uređenja, smatramo dvojbenim primijeniti kaznena djela davanje mita i primanje mita na pojedine sudionike sportskog natjecanja zbog počinjenja koruptivnih radnji s ciljem namještanja rezultata navedenih natjecanja. Smatramo prijepornim inkriminirane radnje pojedinih sudionika sportskih natjecanja obuhvatiti navedenim kaznenim djelima i u situaciji kada bi se te sudionike podvelo pod pojam odgovorne osobe u smislu KZ-a, s obzirom na distinkciju javnog od privatnog sektora u koje spadaju i sportska natjecanja. To se ponajprije odnosi na trenere i igrače. Naime, kaznena djela davanja i primanja mita spadaju u djela kojima se štiti javni sektor, odnosno javna ovlast i službena dužnost. Stoga smo mišljenja da bi valjalo kritički preispitati zauzeta pravna stajališta, koja su bila predmet istraživanja.

Zaključno, smatramo da bi bilo nužno, kroz noveliranje KZ-a, a proširujući postojeći katalog inkriminacija, propisati nova kaznena djela kojima bi se sankcionirale inkriminirane koruptivne radnje (aktivnog i pasivnog) podmićivanja koje su počinjene s ciljem namještanja, odnosno manipulacije rezultatima sportskih natjecanja. Taj prijedlog je i u skladu s europskom pravnom stečevinom koja nameće obvezu tzv. obligatornog kažnjavanja počinitelja kaznenog djela koje uključuje manipulaciju sportskim natjecanjima kada je riječ o koruptivnim radnjama, u koje kao tipično spada i podmićivanje. 


\section{LITERATURA}

\section{Knjige i radovi}

1. Anić, Š., Klaić, N., Domović, Ž., Rječnik stranih riječi, Sani-plus, Zagreb, 2002.

2. Bačić, A., Bačić P., „Lisabonski ugovor i novi start europskog sportskog prava“, Zbornik radova Pravnog fakulteta u Splitu, Split, 4/2011.

3. Bačić, A., Bačić P., ,Stadion i ustavno pravo: treba li sport i sportska prava shvaćati ozbiljno?“, Zbornik radova Pravnog fakulteta u Splitu, Split, 2/2010.

4. Bačić, F., Pavlović, Š., Kazneno pravo - posebni dio, Informator, Zagreb, 2001.

5. Bačić, F., Pavlović, Š., Komentar Kaznenog zakona, Organizator, Zagreb, 2004. Uvod (1. Legislativna kronologija).

6. Bačić, F., „Korupcija i antikorupcijsko kazneno pravo“, Hrvatski ljetopis za kazneno pravo i praksu, 2000.

7. Bejaković, P., Vukšić, G., Bratić, V., „Veličina javnog sektora u Republici Hrvatskoj“, Hrvatska i komparativna javna uprava, Zagreb, 2011.

8. Borković, I., Službeničko pravo, Informator, 1999.

9. Carić, M., „Pojam načela pravičnog postupka pred kaznenim sudom“, Zbornik radova pravnog fakulteta u Splitu, Split, 2006.

10. Čizmić, J., Kačer B., „Pravni izvori sportskog (materijalnog i postupovnog) prava“, u Kačer, H. (ur.), Sportsko pravo (udžbenik), Pravni fakultet Sveučilišta u Splitu, Split, 2018.

11. Derenčinović, D., „Sedam pitanja u vezi s utvrđivanjem pojma „odgovorne osobe“ u hrvatskom kaznenom pravu i sudskoj praksi“, Pravo i porezi, Zagreb, br. 9., 2003.

12. Derenčinović, D., Cvitanović, L., Munivrana V., Turković, K., Posebni dio kaznenog prava, (ur.) Derenčinović, D., Pravni fakultet Sveučilišta u Zagrebu, Zagreb, 2013.

13. Dragičević Prtenjača, M., Kaznenopravni aspekti pasivnog podmićivanja u hrvatskom pravnom sustavu, Zagreb, 2014. (doktorska disertacija).

14. Drmić, A., „Vrste povreda službene dužnosti i disciplinske sankcije“, Hrvatska javna uprava, Zagreb, 2010.

15. Čejović, B., Krivično pravo: Posebni deo, Naučna knjiga, Beograd, 1988.

16. Galiot, M., Aktivno podmićivanje u hrvatskom kaznenom pravu i praksi, Zagreb, 2018. (doktorska disertacija).

17. Galiot, M., ,Oduzimanje imovinske koristi u kontekstu međunarodne pravne stečevine i suzbijanja podmićivanja“, Zbornik Pravnog fakulteta Sveučilišta u Rijeci, 1/2017.

18. Ivičević Karas, E., Kos, D., „Primjena načela ne bis in idem u hrvatskom kaznenom pravu“, Hrvatski ljetopis za kazneno pravo i praksu, Zagreb, 2012.

19. Jovanović, Z., „Prava i dužnosti državnih službenika u Republici Srbiji“, Zbornik radova Pravnog fakulteta u Nišu, Niš, 2010.

20. Kačer, H., Kačer B., „Osobe (ili subjekti) u sustavu sporta u hrvatskom pravu“, u Kačer, H. (ur.), Sportsko pravo (udžbenik), Pravni fakultet Sveučilišta u Splitu, Split, 2018. 
21. Kačer, H., Kačer B., Čizmić, J., „Citius-Altius-Fortius (Više, brže, jače)“, u Kačer, H. (ur.), Sportsko pravo (udžbenik), Pravni fakultet Sveučilišta u Splitu, Split, 2018.

22. Kačer, H., Perkušić, A., Ivančević-Kačer, B., „Postoji li u Republici Hrvatskoj (kvalitetno) sportsko pravo“, Zbornik radova Pravnog fakulteta u Splitu, 4/2012.

23. Kurtović, A., Krstulović Dragičević A., Kazneno pravo (Temeljni pojmovi i instituti), Udžbenici Sveučilišta u Splitu, Split, 2014.

24. Pajčić, M., Sokanović, L., „Manipulacija rezultatima sportskih natjecanja Kaznenopravna odgovornost za kazneno djelo prijevare“, Zbornik radova Pravnog fakulteta u Splitu, Split, 4/2011.

25. Primorac, D., „Suzbijanje manipulacije sportskim natjecanjima prema Konvenciji Vijeća Europe Cets broj 215“, Zbornik radova Pravnog fakulteta u Splitu, 2/2020.

26. Primorac, D., „Šport i protupravna ponašanja“, u Kačer, H. (gl. ur.), (Uvod u) Sportsko pravo, Inženjerski biro, Zagreb, 2009.

27. Renucci, J. F., Droit europeen des droits de l'homme, Contentieux europeen, L. G. D. J., Paris, 2010.

28. Sokanović, L., Šinković Z., Pajčić M., „Utaja poreza i drugih javnih davanja u sportu“, Zbornik radova Pravnog fakulteta u Splitu, Split, 4/2012.

29. Tulić, A., Krivična djela protiv službene dužnosti, str. 18 - dostupno na: www. pravnadatoteka,hr/pdf(Krivična\%20djela\%20službene\%20dužnosti.pdf

\section{Izvori s interneta}

1. www.eur-lex.europa.eu

2. www.sdus.gov.hr

3. https://eur-lex.europa.html?uri=cellar

4. www.ijf.hr>javni-sektor>drzavni-sektor

5. https://sudskapraksa.csp.vsrh.hr

6. www.usud.hr

\section{Presude Ustavnog suda Republike Hrvatske}

1. poslovni broj U-III-602/2014 od 5. srpnja 2016.

2. poslovni broj U-III-1091/2014 od 5. srpnja 2016.

3. poslovni broj U-III-681/2014 od 5. srpnja 2016.

\section{Presude Vrhovnog suda Republike Hrvatske}

1. poslovni broj I Kž-7/2016-7 od 11. rujna 2019.

2. poslovni broj I Kž-662/2006-5 od 23. listopada 2007.

3. poslovni broj I Kž-Us-82/2012-8 od 18. prosinca 2013.

4. poslovni broj I Kž-Us-6/2015-8 od 17. svibnja 2017.

5. poslovni broj I Kž-Us-35/16-6 od 1. lipnja 2016.

6. poslovni broj IV Kž-14/06-3 od 12. travnja 2006.

7. poslovni broj III Kr-194/08-3 od 3. ožujka 2009. 
8. poslovni broj IV Kž-107/16-2 od 12. prosinca 2006.

9. poslovni broj I Kž-652/13-4 od 26. studenoga 2013.

10. poslovni broj IV Kž-19/05-3 od 19. travnja 2005.

11. poslovni broj I Kž-317/04-3 od 7. ožujka 2006.

\section{Odluka Visokog upravnog suda Republike Hrvatske}

1. poslovni broj Usoz-97/2014-4 od 27. veljače 2015.

\section{Presude županijskih sudova}

1. Županijskog suda u Zagrebu poslovni broj K-Us-9/2011 od 13. prosinca 2011.

2. Županijskog suda u Zagrebu poslovni broj K-Us-4/2005 od 23. listopada 2007.

3. Županijskog suda u Zagrebu poslovni broj K-Us-50/2012 od 25. ožujka 2014.

4. Županijskog suda u Zagrebu poslovni broj Kov-Us-43/14 od 18. lipnja 2014.

5. Županijskog suda u Osijeku poslovni broj K-Us-10/2015-6 od 14. listopada 2015.

\section{RESPONSIBILITY FOR RESULTS FITTING OF SPORTS COMPETITIONS- BRIBERY ASPECTS}

The processes of modernization, globalization and consumerism have significantly changed the attitude of people towards sports and sports competitions in modern society. Sports competitions are becoming a dramatic expression of real capitalist events and relationships in which, in addition to achieving sports results, the main goal is to maximize profits. In order to achieve this, persons in the sports system, as well as entities associated with betting, often take action with the aim of fixing the results of sports competitions. It is primarily a corruption phenomenon that is subject to sanctions according to the norms of criminal law. This paper will analyze the positive legal regulation of criminal liability for bribery for rigging the results of sports competitions. The manifestations of these actions will also be considered and the possibility of punishing the participants in these illegal actions will be critically re-examined only from the aspect of criminal liability for committing the act of giving and receiving bribes. In criminal practice, it has been controversial to include participants in sports competitions under the term responsible person as defined in the Criminal Code, and whether corrupt actions taken to manipulate the results of sports competitions can be classified as official actions in the context of liability for so-called classic forms of active and passive bribery. Starting from the positive legal system in Croatian legislation and legal understandings of the so-called. Uskok practice, an attempt was made to investigate the extent to which it is possible to prosecute and punish participants in sports competitions for bribery for rigging the results. It concludes that there is a need "de lege ferenda" to change the legal framework and critically review the legal positions taken in criminal practice.

Key words: sport, sports competition, match-fixing, criminal liability, bribery 